\title{
Character distribution and phylogeny of the dissorophid temnospondyls
}

\author{
Rainer R. Schoch \\ Staatliches Museum für Naturkunde Stuttgart, Rosenstein 1, 70191 Stuttgart; Germany. E-mail: rainer.schoch@smns-bw.de
}

\begin{abstract}
Received 31 January 2012

Accepted 9 March 2012

Published 3 August 2012

The phylogeny of the largely Permian temnospondyl group Dissorophidae is analyzed for the first time. Although hampered by poor preservation and incompleteness of finds, new data add substantially to our knowledge of the group. An analysis of 25 taxa and 70 characters gave the following results. (1) The Dissorophidae and Trematopidae each form monophyletic groups that are more closely related to one another than either of them is to amphibamids. Olsoniformes and Amphibamidae are each defined by clear-cut autapomorphies, making it unlikely that amphibamids are dwarfed dissoro-

Key Words

amphibians

Cacopinae

Dissorophinae

Dissorophoidea

Permian

Texas

Trematopidae

phids or olsoniforms. (2) Ecolsonia nests with Fedexia at the base of the Trematopidae. (3) The Dissorophidae falls into two major clades, the Dissorophinae sensu stricto (Dissorophus, Broiliellus) and the Cacopinae (Cacops, Kamacops, Zygosaurus). The Cacopinae is much better supported than the Dissorophinae. Platyhystrix and Aspidosaurus form successive sister taxa of all other dissorophids. Incompletely known dissorophids were found to nest as follows: (a) Brevidorsum, the Admiral Taxon and Rio Arriba Taxon at the base of the Cacopinae and (b) Conjunctio multidens forms an unresolved trichotomy with dissorophines and cacopines. The significance of osteoderms in dissorophid phylogeny is found to be much smaller than hitherto considered.
\end{abstract}

\section{Introduction}

The dissorophid temnospondyls have long formed a neglected group. This is astonishing, as they encompass some of the most extreme morphotypes among early tetrapods, ranging from sail-backed Platyhystrix over heavily armoured Dissorophus to Cacops with its huge otic notch. They depart considerably from the common theme of temnospondyls - a parabolic-skulled, aquatic or amphibious predator in the 1-3 m range. Their smaller size, derived skull morphology, and the possession of extensive but highly variable osteoderms on the back of the trunk form outstanding characters. Dissorophids represent one of the few non-amniote clades that managed to dwell dry land and dominate settings in the uplands of late Carboniferous and Permian terrestrial environments (Reisz et al. 2009; Schoch 2009).

Dissorophids include twelve genera and some 21 species, most of which are known from the Permian of Texas and adjacent areas in North America (Carroll 1964). Although there is a rather implicit idea about what a dissorophid is (Berman et al. 1985), taxa keep floating around between the Dissorophidae and Trematopidae in recent phylogenetic analyses (Schoch \& Ru- bidge 2005; Berman et al. 2010; Polley \& Reisz 2011). In particular, the relationships between the Dissorophidae, Trematopidae, and Amphibamidae form a matter or interest. This field has come under close observation also by researchers from other life sciences, since amphibamids have been argued (based on a broadening range of data) to form the stem-group of batrachians (Anderson et al. 2008) or all lissamphibians (Milner 1988, 1993; Ruta et al. 2003).

Recent publications on two new species of Cacops have triggered studies on dissorophids, after the new material from cave deposits at Fort Sill, Oklahoma, showed an unprecedented quality of preservation (Reisz et al. 2009; Fröbisch \& Reisz 2012). The numerous characters exposed in these new specimens, some of which were recognized for the first time, have prompted a thorough re-examination of existing material from other localities. Therefore, the present study focuses on the distribution of character-states within the group and their significance on dissorophid monophyly. It cannot provide a taxonomic revision of the group, which requires more extensive reviews of taxa and their composition. The objective of this study is twofold: (1) discuss all characters that were proposed to be significant 
to dissorophid phylogeny, and (2) perform a cladistic analysis of as many taxa as possible within the group.

\section{Material}

The following range of material forms the base of the present study, $85 \%$ of which has been examined personally.

Field Museum, Chicago: Broiliellus texensis (FMNH 41), B. arroyoensis (FMNH UC 431), B. olsoni (FMNH 31189), "Broiliellus" novomexicanus (FMNH 744), Conjunctio multidens (FMNH UC 673, type), Dissorophus sp. (FMNH UR 430),

Museum für Naturkunde, Leibniz-Institut für Evolutions- und Biodiversitätsforschung: Zygosaurus lucius (MB.Am 1360, cast).

Harvard University, Cambridge, Museum of Comparative Zoology: Aspidosaurus chiton (MCZ 1477), Broiliellus brevis (MCZ 1424), Admiral Taxon ("Conjunctio" sp.: MCZ 2369), Dissorophus multicinctus (MCZ 4176, 4179, 4189, 4191, 4192, 4194), Platyhystrix rugosus (MCZ 2414, 2415, 2982), Dissorophidae gen. et sp. nov. (MCZ 1911).

National Museum of Natural History, Washington: Aspidosaurus chiton (USNM 407835), Dissorophus multicinctus (USNM 21904, 23726), Phonerpeton pricei (USNM 8641, 8644).

American Museum of Natural History, New York: Alegeinosaurus aphthitos (AMNH 4756), Aspidosaurus glascocki (AMNH 4864, type), Dissorophus multicinctus (AMNH 4343, 4580, 4593, 23780), Phonerpeton sp. (AMNH 7150), Platyhystrix rugosus (AMNH 11544, 11545),

Oklahoma Museum of Natural History, Norman: Cacops morrisi (OMNH 53073, 53077, 73206)

Paleontological Institute of the Russian Academy of Sciences, Moscow: Kamacops acervalis (PIN 1758/332, 3817/1).
Staatliches Museum für Naturkunde, Stuttgart: Cacops morrisi (SMNS 91418), Sclerocephalus haeuseri (SMNS 91500).

University of California, Museum of Paleontology, Berkeley: Rioa Arriba Taxon ("Broiliellus" novomexicanus, UCMP 40103).

Abbreviations

Anatomical. ca, carotid foramen; ch, choana; df, denticle field; e, ectopterygoid; eo, exoccipital; ex-oc, external osteoderm; f, frontal; ic, intercentrum; in-os, internal osteoderm; ipf, interpremaxillar fontanelle; ipv, interpterygoid vacuity; ivf, intervomerine fontanelle; j, jugal; 1 , lacrimal; lee, lateral exposure of ectopterygoid; lep, lateral exposure of palatine; lw, lateral wing of parasphenoid; $\mathrm{m}$, maxilla; $\mathrm{n}$, nasal; op, opisthotic; p, parietal; pap, parapophysis; par, prearticular; pc, pleurocentrum; pl, palatine; pm, premaxilla; po, postorbital; pof, postfrontal; pp, postparietal; ppl, palatal plates; prf, prefrontal; ps, parasphenoid; pt, pterygoid; q, quadrate; q-p, dorsal process of quadrate; qj, quadratojugal; sm, septomaxilla; sq, squamosal; st, supratemporal; stf, subtemporal fenestra; $t$, tabular; tp, transverse process of pterygoid; v, vomer.

Institutional. (Tab. 1): CMP, Carnegie Museum, Pittsburgh; MNG, Museum der Natur Gotha; TMM, Texas Memorial Museum, University of Texas, Austin.

\section{Characters}

The characters discussed in the present section are derived from different previous studies: \# 1-24 are informative cranial characters based on Schoch \& Rubidge (2005); \# 25-38 are based on Ruta \& Bolt (2006), and \# 39-54 are from literature as cited by Polley \& Reisz (2011). All additional characters are based on findings of the

Table 1. List of taxa analyzed, material, and key references. Material examined personally marked $\left(^{*}\right)$.

\begin{tabular}{|c|c|c|}
\hline Terminal taxon & Material & Literatur \\
\hline Dendrerpeton acadianum & *AMNH & Holmes et al. (1998) \\
\hline Sclerocephalus haeuseri & *GPIM, *SMNS, *SPG & Schoch \& Witzmann (2009) \\
\hline Micromelerpeton credneri & *SMNS, *GPIM & Boy $(1972,1995)$ \\
\hline Platyrhinops lyelli & ${ }^{*} \mathrm{MB},{ }^{*} \mathrm{AMNH}$ & Clack \& Milner (2010) \\
\hline Doleserpeton annectens & *UCMP, *USNM & Bolt (1969), Sigurdsen \& Bolt (2009) \\
\hline Acheloma cumminsi & OMNH, *USNM & Polley \& Reisz (2011) \\
\hline Phonerpeton pricei & *AMNH, *MCZ, *USNM & Dilkes (1990) \\
\hline Ecolsonia cutlerensis & CMP & Berman et al. (1986) \\
\hline Fedexia striegeli & CMP & Berman et al. (2010) \\
\hline Anconastes vesperus & CMP & Berman et al. (1987) \\
\hline Tambachia trogallas & MNG & Sumida et al. (1998) \\
\hline Platyhystrix rugosus & *AMNH, *MCZ, *USNM & Berman et al. (1981) \\
\hline Aspidosaurus binasser & TMM & Berman \& Lucas (2003) \\
\hline Dissorophus multicinctus & *AMNH, MCZ & Williston (1910b), DeMar (1968) \\
\hline Broiliellus texensis & *AMNH, FMNH & Williston (1914), Carroll (1964) \\
\hline Broiliellus brevis & *MCZ & Carroll (1964) \\
\hline Broiliellus olsoni & FMNH & DeMar (1967) \\
\hline Brevidorsum profundum & *MCZ & Carroll (1964) \\
\hline Conjunctio multidens & FMNH & Case \& Williston (1913); Carroll (1964) \\
\hline Admiral Taxon (“Conjunctio" sp.) & *MCZ & Carroll (1964), present paper \\
\hline Rio Arriba Taxon (“Aspidosaurus" novomexicanus) & *UCMP & present paper \\
\hline Cacops aspidephorus, & FMNH & Williston (1910a), \\
\hline C. morrisi & *OMNH & Reisz et al. (2009) \\
\hline Kamacops acervalis & *PIN & Gubin (1980); Schoch (1999) \\
\hline Zygosaurus lucius & *MB (cast) & Eichwald (1848) \\
\hline
\end{tabular}


present study if not mentioned otherwise. Character states are illustrated in Figs $1-4$

1. Laterally exposed palatine (LEP). Palatine overplated by jugal and lacrimal with no lateral exposure (0); palatine wedging between lacrimal and jugal to make contribution to skull roof and orbital margin (1); maxilla contributes to orbital margin by separating jugal and lacrimal in the absence of lateral exposure of palatine (2) (based on Sumida et al. 1998); lateral exposure of palatine present and excluded from orbital margin by jugal and lacrimal contact (3). An LEP was long believed to be absent in micromelerpetontids, but shown by Boy (1995) to be present in adults.

2. Dorsal quadrate process (DQP). Quadrate having smooth posterodorsal side $(0)$; quadrate with prominent dorsoposterior outgrowth, the quadrate process (1). With the exception of larvalneotenic taxa (Branchiosauridae, Micromelerpetontidae), the derived condition has been reported from all dissorophoids (Bolt 1969). It is specifically present in all studied dissorophids and trematopids.

3. Vomerine depression. Ventral surface of vomers flat and element divided into anterior and posterior portion by transverse ridges that may or may not bear transverse tooth row (0); single unpaired depression in anterior portion of vomers that may or may not house an opening (1).

4. Parasphenoid dentition. Basal plate of parasphenoid bearing shagreen of small teeth (denticles) anteromedially (0); plate entirely smooth (1). In the Dissorophoidea, the derived condition is reported from two different families, the Branchiosauridae (Boy 1972, 1987) and Dissorophidae (Berman et al. 1985).

5. Parasphenoid denticle field. Well established, with triangular outline and with apex reaching onto base of cultriform process $(0)$; denticle field greatly expanded anteriorly to cover most of the cultriform process (1). Within Dissorophoidea, the derived condition is only known in some amphibamids (Micropholis, Pasawioops, Amphibamus, Platyrhinops)

6. Parasphenoid basal plate. Roughly quadrangular dimensions, as long as wide $(0)$; basal plate much shorter than wide, reaching about half the width (1)

7. Vomerine denticle field. Vomer covered with a more or less dense shagreen of teeth in addition to obligatory fang pair (0); shagreen confined to juvenile stages and/or absent throughout ontogeny (1).

8. Vomerine fangs. Vomer lacking fangs in its medial portion, outside lateral tooth arcade, but having smaller accessory teeth in that region (0); vomer with additional fang pairs posterior to midvomerine depression (1).

9. Pterygoid-vomer contact. Suture between pterygoid (palatine ramus) and vomer (0); pterygoid contacting only palatine (or ectopterygoid) and lacking suture with vomer (1).

10. Pterygoid flange. Palatine ramus of pterygoid merging continuously into basipterygoid ramus (0); palatine ramus broadening abruptly to form a pronounced transverse flange, giving the lateral margin a rectangular shape (1). The newly-defined apomorphic state is only present in dissorophids; in trematopids and amphibamids, the flange is rounded.

11. Palatine, ectopterygoid. Palatine and ectopterygoid much wider than maxilla $(0)$; palatine and ectopterygoid reduced to narrow struts not wider than adjoining maxilla (1). The two bones are here considered together, because their width evolved in parallel and was probably linked.

12. Interpterygoid vacuity. Roundish or oval in outline (0); greatly expanded laterally at mid-level (1).

13. Narial flange. Ventral (inner) side of prefrontal, lacrimal, and nasal smooth (0); inner side of these bones forming complicated bar-like structure (narial flange), permitting contact with antorbital bar (1).

14. Prefrontal process. Prefrontal forming simple suture with lacrimal laterally $(0)$; prefrontal underplating lacrimal widely by means of ventral prefrontal process contacting palatine (1)
15. Tabular size. Tabular narrower than postparietal, but reaching almost same size as latter (0); tabular minute and laterally constricted by unique enlargement of otic notch (1).

16. Tabular-squamosal contact. Tabular and squamosal widely separated by supratemporal $(0)$; squamosal meeting tabular, excluding supratemporal from otic notch (1).

17. Postparietal length. Postparietal forming transversely rectangular or quadrangular element $(0)$; postparietal abbreviated and reduced to narrow, poorly ornamented strut at posterior margin of skull table (1).

18. Squamosal-supratemporal suture. Nearly as long as supratemporal itself (0); foreshortened, reaching only one third or less of length of supratemporal (1).

19. Supratympanic flange (= semilunar flange in Schoch \& Rubidge 2005, terminology following Bolt 1974a). squamosal continuously ornamented around margin of otic notch (0); squamosal having dorsally exposed and ornamented area (supratympanic flange) stepping abruptly into steeply aligned, poorly ornamented portion (1).

20. Semilunar flange (= supratemporal flange of Schoch \& Rubidge 2005). supratemporal without ventral projection into otic notch $(0)$; supratemporal forming marked ventral flange participating in medial bordering of otic notch (1).

21. Prefrontal-postfrontal. Firmly sutured on the dorsal side, excluding the frontal from the orbital margin (0); both elements separated by frontal, at least dorsally (1). Whereas this character varies in some capitosaurs (Schoch 2000), it has not been found to do so in dissorophoids. Notably, the stratigraphically earliest micromelerpetontids (Limnogyrinus elegans), branchiosaurids (Branchiosaurus salamandroides) and amphibamids (Amphibamus grandiceps, Platyrhinops lyelli) have the plesiomorphic condition, whereas this is not known from any trematopid or dissorophid.

22. Interorbital width. Narrow to moderately wide interorbital region in the $0.2-0.24$ range (interorbital width/skull length) (0); or substantially wider (0.27-0.33) (1). Among the outgroups, Dendrerpeton is unusual in having a wide interorbital region, and therefore Sclerocephalus has been taken as guide to the primitive condition.

23. Palpebral ossifications. No ossifications other than sclerotic ring (0); numerous palpebral ossicles at medial margin of sclerotic ring (1). This character, first documented by Boy (1972) in Micromelerpeton, and later emphasized by Daly (1994) for amphibamids, is not confined to Micromelerpetontidae and Amphibamidae as often held. It is at least also known from Broiliellus brevis (observation by author) but probably more widespread among the dissorophoids. The delicacy of ossifications and the substantial variation in their thickness across taxa make this character difficult to assess in many specimens, and even slight disarticulation poses major problems.

24. Stapes. Stapes with pronounced dorsodistal curvature directed towards dorsally located otic notch (0); or abbreviated without dorsodistal curvature, directed mostly laterally towards vertically aligned otic notch (1). Since Schoch \& Rubdige (2005), the derived character-state has been coded only for amphibamids (e.g., Polley \& Reisz 2011), but the now-available data indicate that the apomorphic orientation of the stapes is shared by trematopids and dissorophids, as well.

25. Prefrontal-jugal contact. Absent (0); present (1). The derived state is found in Sclerocephalus (representing the vast stereospondylomorph clade and eryopids that all share this feature). The resulting pattern in which the lacrimal does not border the orbit evolved convergently in Cacops morrisi (Reisz et al. 2009), where it results from an anterior expansion of the LEP, unlike in Sclerocephalus where the jugal extends further anteriorly.

26. Maxilla dentition. Extending posterior to the level of the posterior margin of the orbit $(0)$; terminating at the level of such margin or anterior to it (1). This is a genuine dissorophid character, most clearly exemplified by Cacops. 

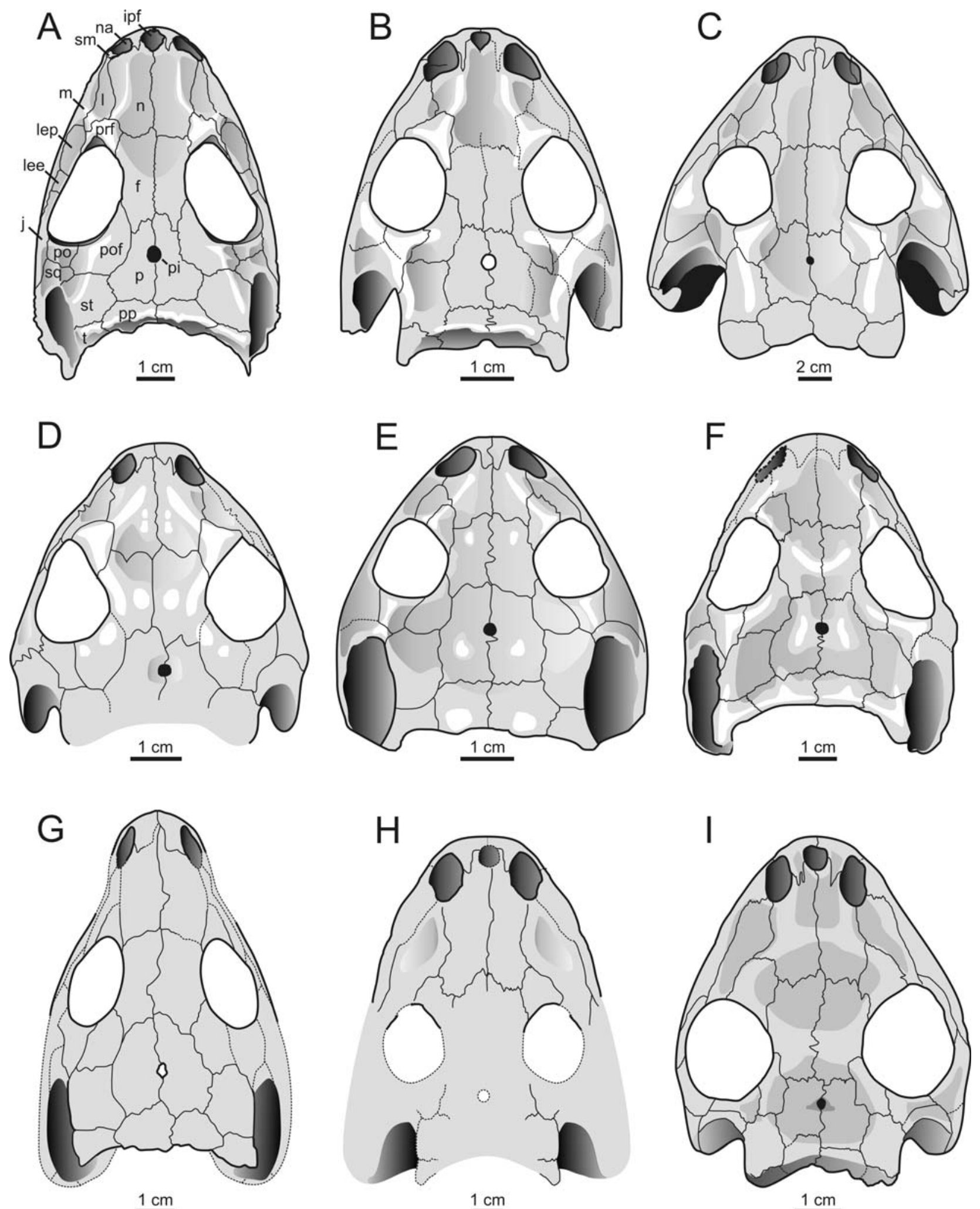

Figure 1. Skull roofs of selected dissorophids in dorsal view. A. Cacops morrisi (OMNH 53073); B. Rio Arriba Taxon ("Broiliellus novomexicanus", UCMP 40103); C. Dissorophus multicinctus (MCZ 2122, USNM 21904); D. Broiliellus olsoni (FMNH 31189); E. Broiliellus texensis (Williston 1914); F. Broiliellus brevis (MCZ 1424, 1747); G. Platyhystrix rugosus (Berman et al. 1981); H. Aspidosaurus binasser (Berman \& Lucas 2003); I. Admiral Taxon (MCZ 2369, "Conjunctio" sp. of Carroll 1964).

27. Skull outline. Absence (0) or presence (1) of inward inflection of skull outline in dorsal view at the level of the maxilla-premaxilla suture.
28. Septomaxilla. At posterior rim of naris (0); at mid-level of naris, pointing inside (1). The derived state is present in all trematopids and dissorophids, differing from all other temnospondyl groups. (New character). 

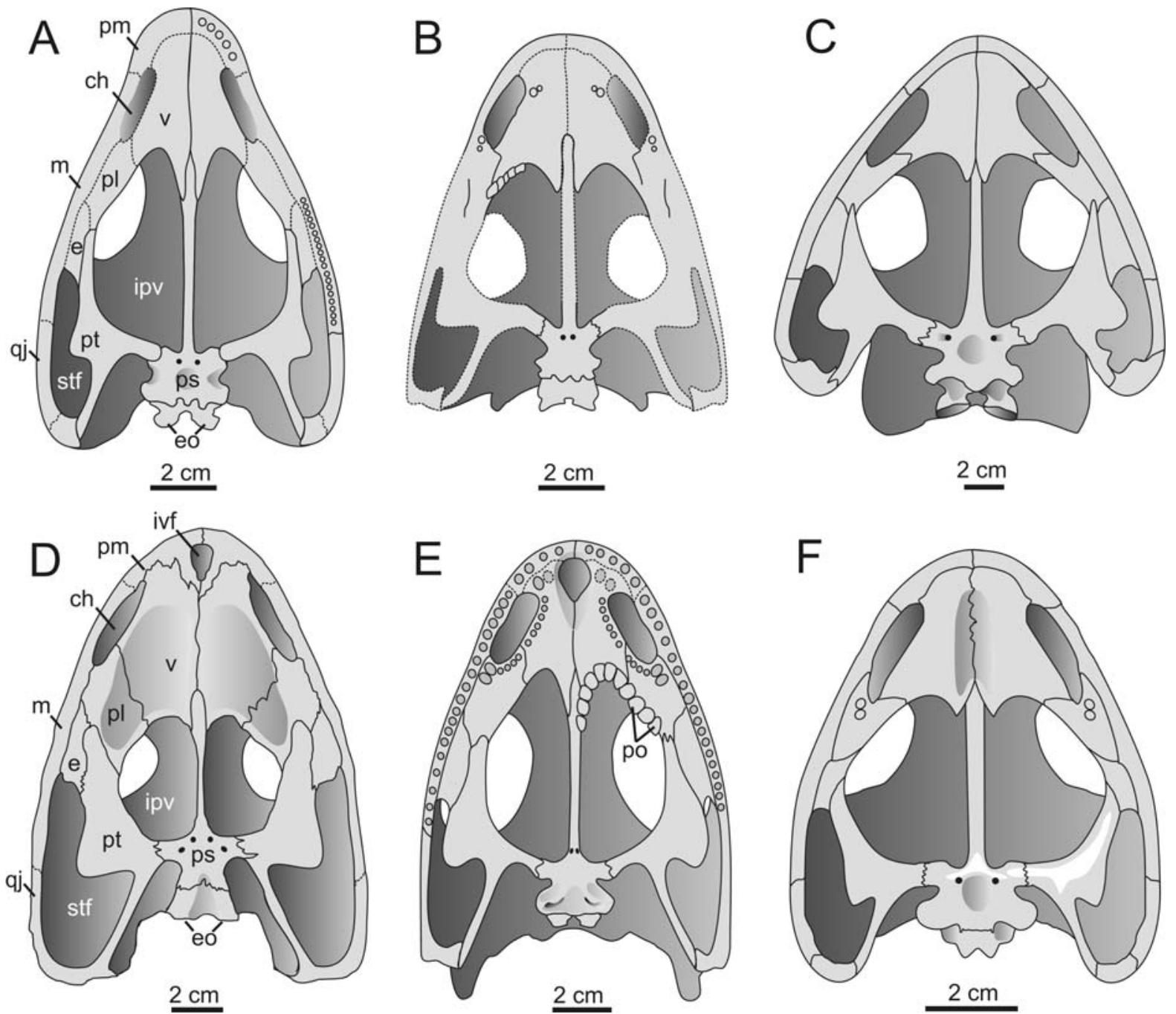

Figure 2. Palates of selected dissorophids in ventral view. A. Platyhystrix rugosus (Berman et al. 1981); B. Aspidosaurus binasser (Berman \& Lucas 2003); C. Dissorophus multicinctus (MCZ 2122); D. Kamacops acervalis (Schoch 1999); E. Cacops morrisi (OMNH 53073); F. Broiliellus brevis (MCZ 1424, 1747).

29. Parietal width. More (0) or less (1) than two and a half times as long as wide.

30. Postparietal length. Postparietals less (0) or more than (1) four times wider than long.

31. Postorbital. Narrowing to an acute posterior point $(0)$; not narrowing, ending blunt (1).

32. Vomer (posterior projection). Absent (0) or present (1).

33. Vomer (tooth row). Vomer with ( 0 ) or without (1) a toothed, raised crest running anteroposteriorly and lying mesial to the choana.

34. Palatine and interpterygoid vacuity. Palatine partially or fully excluded from vacuity by pterygoid $(0)$; bordering vacuity along its entire medial margin (1). (Reformulated)

35. Cultriform process. Moderately wide and flat on ventral side (0); throughout thin and round in cross-section (1)

36. Exoccipital-tabular contact. Absent (0); present (1).

37. Exoccipital-postparietal contact. Present (0); absent (1). (Coding reverted from Polley \& Reisz 2011), because absence is clearly exclusive to cacopines in the present set of taxa).

38. Position of jaw articulation. Posterior to (0), level with (1), or anterior to (2) the posterior facets of the exoccipitals.

39. External narial opening. Uniform, oval shaped margin (0); posteriorly expanded at the expense of lacrimal, with distinct anterior and posterior regions giving external naris an overall 'key-hole' shape (1) (Dilkes, 1990).
40. Internarial fenestra. Absent (0); present (1) (Dilkes 1990).

41. Marginal teeth of upper jaw. Uniform in size (0); caniniform teeth on premaxilla and maxilla (1) (Dilkes 1990).

42. Prearticular. Inflection of the prearticular along the medial rim of the adductor fossa: absent (0); present (1) (Dilkes 1990).

43. Ventral border of otic notch. Slopes posteroventrally (0); nearly horizontal (1) (Dilkes \& Reisz 1987). Within the Trematopidae, this character may have been subject to ontogenetic change or scaling, as small trematopids have the plesiomorphic, large ones the apomorphic condition.

44. Median vomerine septum. Absent (0); present (1) (Dilkes \& Reisz, 1987; Dilkes, 1990).

45. Tabular process. Any state between short and absent (0); curves gradually to meet robust quadrate process (1); bent down sharply at approximately a right angle to the dorsal edge of the skull table and fused to the quadrate process (2) (Dilkes \& Reisz 1987).

46. Stapedial foramen. Absent (0); present (1) (Boy 1981; Daly 1994) This character was long believed to separate trematopoids from dissorophids, with the latter considered to lack a foramen, However, Cacops morrisi clearly has a stapedial foramen (OMHN 73106).

47. Knobby exostoses (skull roof). Absent (0); present (1) (Daly, 1994).

48. Subnarial lacrimal process. Long (0); short (1) (Sumida et al., 1998). 

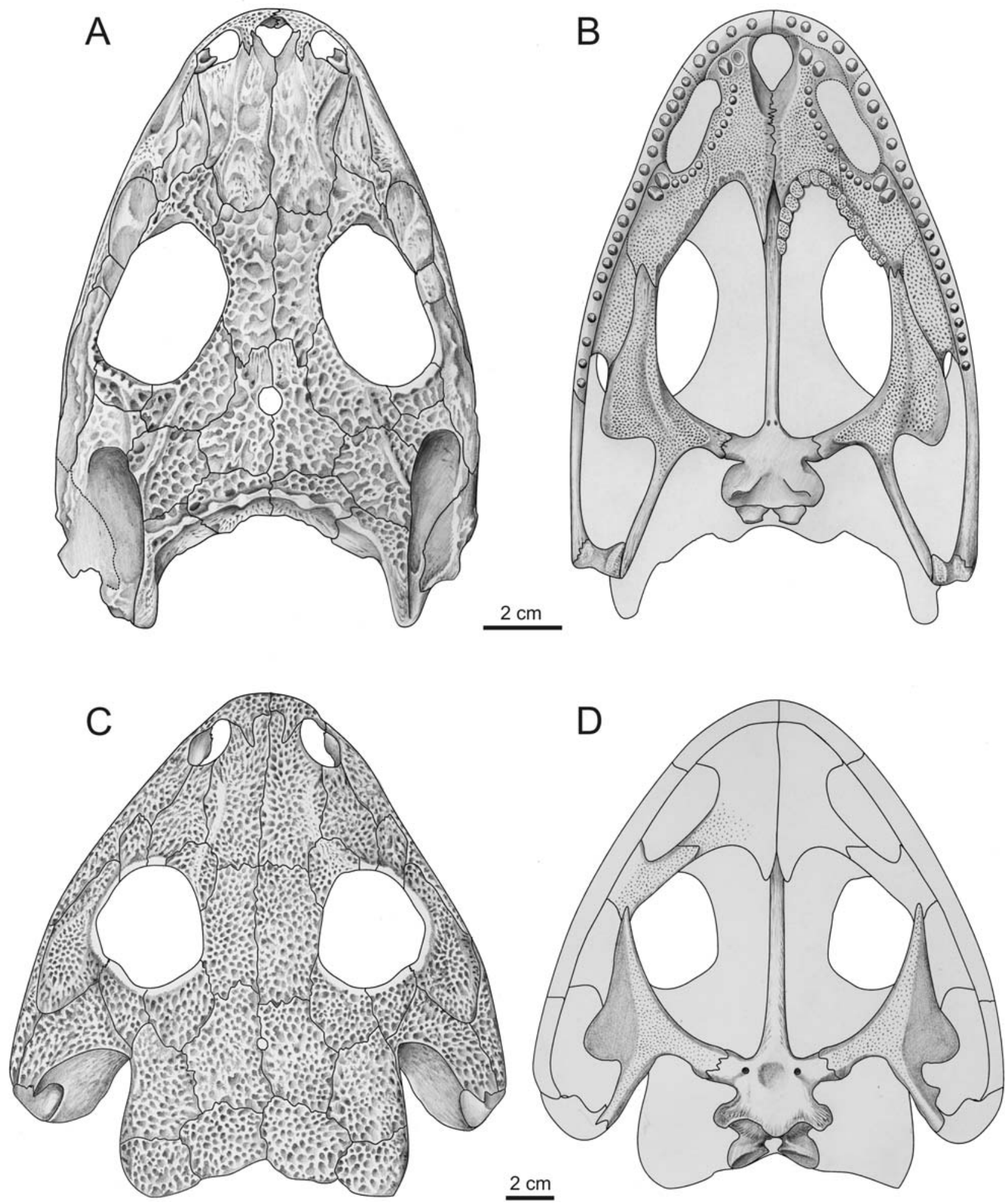

Figure 3. Details of dissorophid cranial anatomy exemplified by Cacops morrisi (A, dorsal; B, ventral, based on OMNH 53073) and Dissorophus multicinctus (C, dorsal; D, ventral, based on MCZ 1221, USNM 21904, 23726).

49. Squamosal. Semilunar curvature of along ventral border of the supratympanic flange: absent (0); present (1) (Berman et al. 1985; Dilkes 1990).

50. Dorsal rim of occiput. Gently ornamented (0); ornament forming marked transverse ridge (1).

51. Ratio of preorbital length to postorbital length. preorbital length greater than postorbital length by more than $10 \%(0)$; pre- orbital and postorbital lengths approximately equal (1); postorbital length greater than preorbital length by greater than $10 \%(2)$.

52. Suborbital bar height. Greater than $10 \%$ of the total midline skull length (0); less than $10 \%$ of the total midline skull length (1).

53. Minimum distance otic notch-posterior orbital margin. Greater than $25 \%$ of the total midline skull length $(0)$; between 10 and 
A $\frac{1 \mathrm{~cm}}{\longrightarrow}$

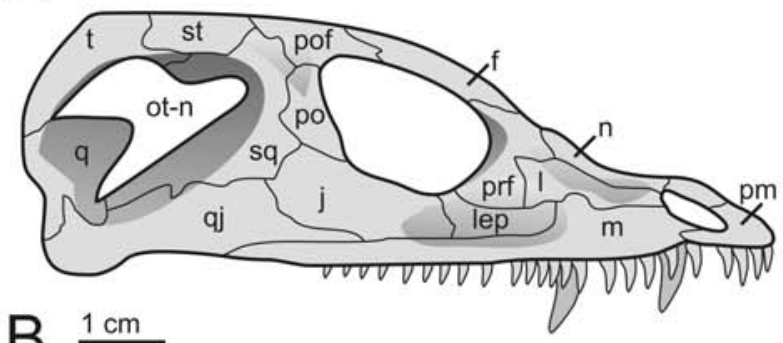

B $1 \mathrm{~cm}$

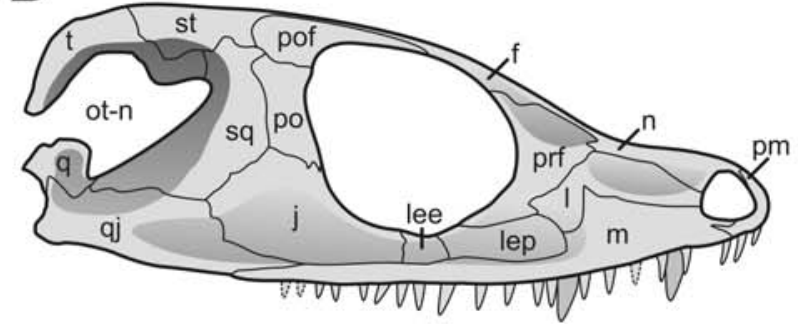

C $1 \mathrm{~cm}$

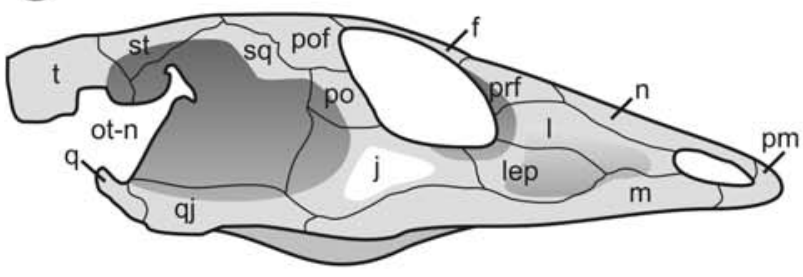

$\mathrm{D}$

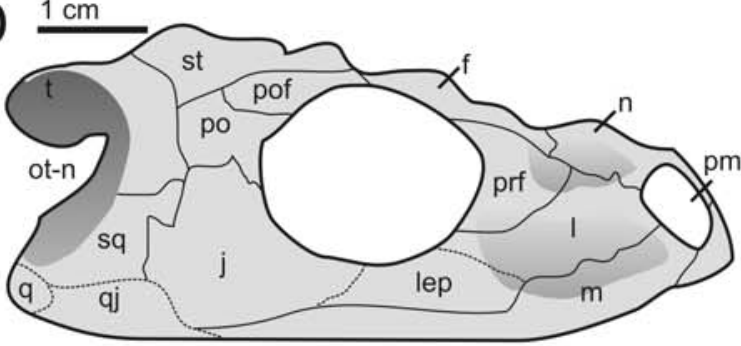

$\mathrm{E} \stackrel{1 \mathrm{~cm}}{\mathrm{~s}}$
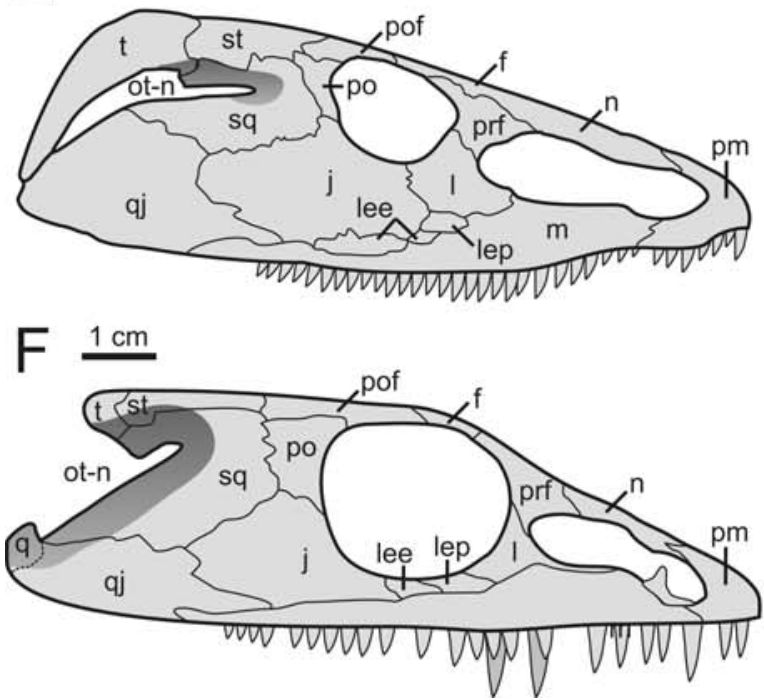

G $\quad 2 \mathrm{~cm}$

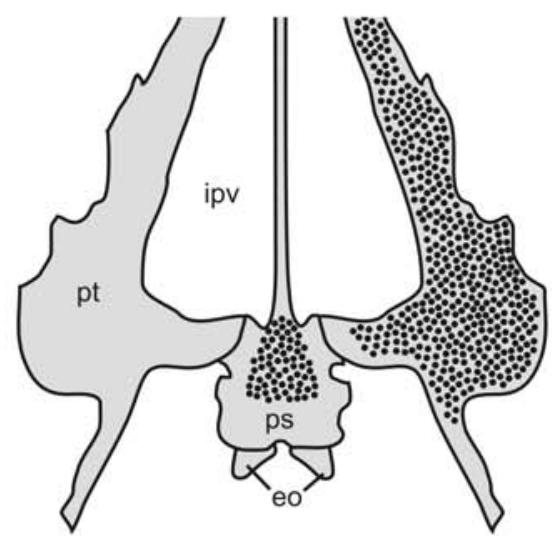

$\mathrm{H} \quad 2 \mathrm{~cm}$

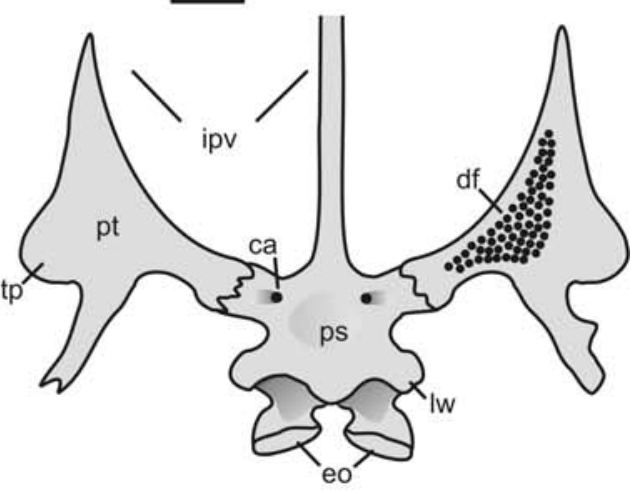

$1 \quad \underline{c m}$

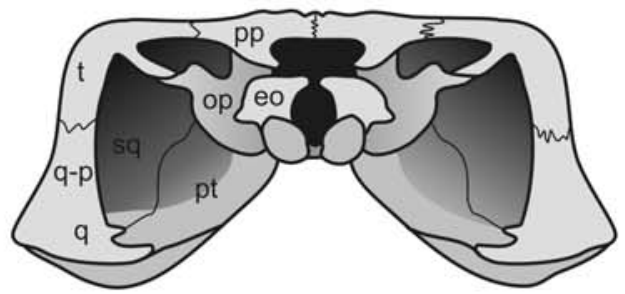

$\mathrm{J} \quad \underline{1 \mathrm{~cm}}$

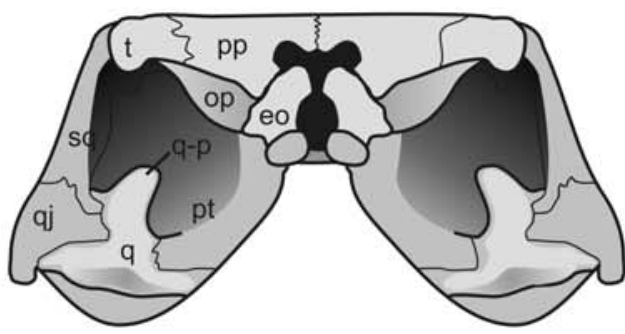

Figure 4. Characters of the otic notch and narial region in selected trematopids and dissorophids. A. Adult Cacops morrisi (Reisz et al. 2009); B. Juvenile Cacops morrisi (Reisz et al. 2009); C. Dissorophus multicinctus (MCZ 1221); D. Broiliellus olsoni (FMNH 31189); E. Acheloma dunni (Polley \& Reisz 2011); F. Phonerpeton pricei (Dilkes 1990); G-H. Ventral view; G. Acheloma dunni (Polley \& Reisz 2011); H. Dissorophus multicinctus (MCZ 1221); I-J. Occipital view; I. Adult Cacops morrisi; J. Phonerpeton pricei (Dilkes 1990). 
$25 \%$ of the total midline skull length (1); less than $10 \%$ of the total midline skull length (2).

54. Basipterygoid articulation. Discrete facet for ball-and-socket joint or overlap (0); firmly sutured at mid-level of widened basipterygoid process (1)

55. Postorbital-supratemporal. Sutured (0); separated by postfrontal (1). This character appears to be polymorphic in Phonerpeton, but obligate in Cacops morrisi; it is unknown in the heavily ornamented taxa (Cacops aspidephorus, Kamacops, Zygosaurus).

56. Intertemporal. Present (0); absent (1). Although a clear-cut character, the intertemporal was lost several times independently in basal temnospondyls. In Sclerocephalus, it has been reported as a polymorphism in several samples (Boy 1988).

57. Osteoderms. Median unpaired osteoderms (one per vertebra) absent (0); or present. (1). (Dilkes \& Brown 2007). DeMar (1966b), who first studied the dissorophid armor in depth, distinguished two major types (see character 58), arguing for their independent evolutionary origin. However, there is no reason to conclude that the inner series of osteoderms is not homologous throughout dissorophids, just because its mode of articulation differs in sub-clades.

58. Osteoderm width. Narrow (0), wide (1). Dissorophus and Broiliellus texensis share wide (internal and external) osteoderms reaching at least the width of the two postparietals. In Aspidosaurus (sensu stricto) and Cacops, the osteoderms are much narrower, not exceeding the maximum width of the transverse processes (DeMar 1966b).

59. Cranial ridges. Dorsal surface of skull roof flush or with gentle ridges on prefrontal, orbital margin, and in the temporal region (0); or with pronounced ridges especially in the snout (1). Although Cacops and Kamacops, the Admiral Taxon, and Rio Arriba Taxon also have these ridges, they are always shallower than in Dissorophus and the three Broiliellus species.

60. Ilium (dorsal process). High and slender, distally not wider than shaft (0); or short and stout, not higher than base is wide, with broadened dorsal end (1). This is one of the more convincing characters shared by trematopids and dissorophids, as it never occurs in other dissorophoids.

61. Parasphenoid plate. Lateral margin with or without moderate posterolateral projection (0); posterolateral wing expanded well beyond the level of the basipterygoid suture. Lateral projections of the basal plate are found in most amphibamids, branchiosaurids, and dissorophids, but they are most pronounced in Broiliellus and Dissorophus. The presence of a projection in state 0 is subject to ontogenetic changes and variation.

62. Carotid artery. Exit foramina for carotid artery located on the parasphenoid plate (0); or at the base of cultriform process (1). The derived state is clearly present in Cacops morrisi and Kamacops, but unkown in other cacopines; it may thus have been more widespread within this group. Dissorophus, Broiliellus, Aspidosaurus, Platyhystrix, and the Rio Arriba Taxon show the plesiomorphic state.

63. Tabular horn. Round or pointed but short (0); or elongated, forming main portion of tabular (1). Within dissorophoids, the derived state is confined to the three Broiliellus species.

64. Jugal. Dorsal surface of jugal regularly ornamented (0); or with large eminence bearing knobby ornament (1). This feature is most pronounced in Dissorophus, but also present in Broiliellus brevis. It is unknown whether the derived state was age- or size-related, but it is certainly absent in Cacops and Kamacops.

65. Parasphenoid muscle scars. The posterior and posterolateral parts of the parasphenoid plate bear gentle depressions or other types of muscle attachments (0); or they house deep pockets for such attachments (1). The derived state is present in Dissorophus and Broiliellus among the dissorophoids, but has also a wide distribution in stereospondyls (Watson 1962; Yates \& Warren 2000).

66. Pointed snout. The tip of the snout is of various width but parabolic to square-shaped (0); or it is pointed (1). Among dissoro- phoids, the pointed snout characterizes Dissorophus and Broiliellus brevis.

67. Interclavicle. Rhomboidal (0), or quadrangular to pentagonal (1). Usually, the dissorophoid interclavicle is also much smaller than that of outgroups, especially in groups other than micromelerpetontids. Within the dissorophoids, the only exception is the interclavicle of Cacops aspidephorus, which bears a posterior stylus similar to that of Ichthyostega (Jarvik 1996) but broader than in stem-amniotes. The different shapes in state 1 are subject to ontogenetic changes and variation in some taxa.

68. Supinator process. Anterodistal region of humerus with supinator process (0); or lacking such process (1). As emphasized by Milner (1990), trematopids share a supinator with more primitive temnospondyls, whereas dissorophids, amphibamids, and branchiosaurids lack it. Adult specimens of Micromelerpeton also have a supinator (Boy 1995).

69. Entepicondylar foramen. Distal end of humerus pierced by an entepicondylar foramen (0); or lacking such opening (1). This is a consistent post-Dendrerpeton feature (Milner 1990).

70. Dorsal eminences. Skull table without major raised areas other than ornamenting ridges $(0)$; or with elevated eminences on the frontal, parietal, postfrontal, and postparietal (1). The apomorphic state is confined to the three species of Broiliellus.

\section{Problematic characters}

- Extended neural spines. In their most extreme form they are unique to Platyhystrix. However, both Cacops aspidephorus and Dissorophus multicinctus have relatively higher neural spines than outgroups. The problem with this character is that it appears to be size-linked, because smaller Cacops (C. morrisi) and Broiliellus have substantially lower spines. Similarity linked to size is here believed to be a problematic feature, especially because not all of the considered taxa are known by fully adult specimens.

- Osteoderm series. The existence of an external series of osteoderms in addition to the internal one was reported by DeMar (1966b) to occur convergently in Dissorophus and Cacops, but not other taxa of dissorophines or cacopines. However, the present state of knowledge is simply too incomplete to identify how many times external osteoderms evolved, but given the complicated biological implications discussed in Dilkes (2009), parallel evolution is not very likely.

- Palatine and pterygoid. Ruta \& Bolt (2006) reported the palatal ramus of the pterygoid forming a butt joint with the posterior margin of the palatine in some amphibamids, alledgedly producing a continuous sheet of bone with the latter. I could not find such a condition in any dissorophoid, and it is certainly not present in any of the examined taxa considered herein.

- Dermal ornament. There are obvious differences in ornament between the various dissorophid genera, but with the current state of knowledge it is unclear whether they fall into discrete types that may be defined as phylogenetically significant states. On a gross scale, Platyhystrix differs from all other taxa by its pebbly ornament, Cacops bears elevated radial ridges and tubercles, whereas Dissorophus has more small-scale polygonal ridges.

\section{Phylogenetic analysis}

Objective

Dissorophoid phylogeny has been hampered by several problems, such as a relatively high homoplasy index within amphibamids and branchiosaurids, the immature state of many branchiosaurid and micromelerpetontid taxa, and the resulting difficulty to compare the lacustrine European with the terrestrial North American taxa. Most importantly, the insufficiently prepared or described material from the red-beds of 
Texas and New Mexico has prevented the inclusion of dissorophid taxa in phylogenetic analyses. These problems have come closer to a resolution recently by the discovery of much better preserved material (Cacops morrisi from Fort Sill, several trematopid taxa: Berman et al. 1985, 2010; Reisz et al. 2009; Polley \& Reisz 2009) and the redescription of existing material (Berman et al. 1981; Dilkes 1990, 2009; Dilkes \& Brown 2007). The present study attempts to summarize this approach by conducting the first inclusive analysis of all reasonably preserved and sufficiently studied dissorophids. Two major questions have guided this cladistic study: (1) do dissorophids form a natural group, and (2) what is their relationship to trematopids?

Taxa

Altogether 25 taxa were considered, with Dendrerpeton sp. and Sclerocephalus haeuseri forming successive outgroups (Holmes et al. 1998; Boy 1988; Schoch \& Witzmann 2009). All other taxa fall within the Dissorophoidea, with emphasis put on the best-known and most completely preserved taxa (see Table 1 for a complete list of material and references).

- Micromelerpetontidae: Micromelerpeton credneri (Witzmann \& Pfretzschner 2003; Boy 1995). This is the most completely known basal dissorophoid, and also represented by large adult specimens (Boy 1995).

- Amphibamidae: Platyrhinops lyelli and Doleserpeton annectens span the wide range of amphibamids, with Platyrhinops retaining many plesiomorphic states, whereas Doleserpeton forms the best-known among of the most derived taxa with respect to the Lissamphibia. Both taxa have been extensively revised recently (Bolt 1969; Clack \& Milner 2010; Sigurdsen \& Bolt 2010).

- Trematopidae: Acheloma dunni (Polley \& Reisz 2011), Anconastes vesperus (Berman et al. 1987), Ecolsonia cutlerensis (Berman et al. 1985), Fedexia striegeli (Berman et al. 2010), Phonerpeton pricei (Dilkes 1990), and Tambachia trogallas (Sumida et al. 1998). The very interesting trematopid Mordex was found to be so different from early descriptions that it needs substantial revision (Milner pers. comm. 2011). I have also omitted Actiobates peabodyi (Eaton 1973) because it was not available for study.

- Dissorophidae (Figs. 1-4): Admiral taxon (Carroll 1964, fig. 19: "Conjunctio" sp.), Aspidosaurus binasser (Berman \& Lucas 2003), Brevidorsum profundum (Carroll 1964), Broiliellus brevis (Carroll 1964), Broiliellus texensis (Williston 1914), Broiliellus olsoni (DeMar 1967), Cacops aspidephorus (Williston 1910a), Cacops morrisi (Reisz et al. 2009), Conjunctio multidens (Case \& Williston 1913; Carroll 1964), Dissorophus multicinctus (Williston 1910b; DeMar 1968), Kamacops acervalis (Gubin 1980; Schoch 1999), Platyhystrix rugosus (Berman et al. 1981), Rio Arriba Taxon (UCMP 40103, present study), and Zygosaurus lucius (Eichwald 1848). The taxon Longiscitula houghae (DeMar 1966a) has not been given separate consideration here, as it has been shown by Milner (2003) to be based on a specimen of Dissorophus multicinctus. The extremely fragmentary material of Iratusaurus (Gubin 1980) and Anakamacops (Li \& Cheng 1999) was not considered here.

\section{Analysis}

Analyses were run on PAUP 3.1 (Swofford 1991). All characters were treated as unordered and weighted equally. In PAUP, analyses were run in the heuristic mode, under ACCTRAN, with the full data set giving 180 MPTs and 138 steps (CI: 0.558, RI: 0.759, RC: 0.423). MacClade 3.0 (Maddison \& Maddison 1992) was used to view changes of biases on taxa and to depict character evolution. Variant analyses comprised the exclusion of wild card taxa (Conjunctio) and poorly known dissorophids (Brevidorsum, Broiliellus olsoni, Zygosaurus). Bremer support values and Bootstrap were calculated in PAUP.

\section{General results}

The phylogenetic topology was not fully resolved, but still gave a comprehensive picture of relationships (Fig. 5). The resulting tree has a monophyletic Dissorophoidea, Amphibamidae, Trematopidae, and Dissorophidae. This is consistent with all recent analyses (see below), but it adds substantially to our knowledge of intradissorophid relationships and the composition of the Trematopidae and Dissorophidae. The nodes supported by synapomorphies or other characters are listed as follows.

1. Dissorophoidea. Micromelerpeton, Amphibamidae, Trematopidae, Dissorophidae. Based on three unambiguous synapomorphies $(1,14,24)$ and two homoplasies $(3 \mathrm{H}, 21 \mathrm{H})$. Supported by 3 steps Bremer and $100 \%$ Bootstrap.

2. Amphibamidae + Olsoniformes. Based on four unambiguous synapomorphies $(2,13,29,33)$ and one homoplasy $(18 \mathrm{H})$. Supported by 3 steps Bremer and $80 \%$ Bootstrap.

3. Amphibamidae (Platyrhinops lyelli + Doleserpeton annectens). Based on one unambiguous synapomorphy (5) and two homoplasies $(15 \mathrm{H}, 17 \mathrm{H})$. Supported by 3 steps Bremer and $80 \%$ Bootstrap.

4. Olsoniformes (Trematopidae + Dissorophidae). Based on six unambiguous synapomorphies (16, 19, 20, 28, 35, 60). Supported by 3 steps Bremer and $100 \%$ Bootstrap.

5. Trematopidae (Ecolsonia, Fedexia, Tambachia, Anconastes, Phonerpeton, and Acheloma). Based on two unambiguous synapomorphies $(39,46)$ and one homoplasy $(32 \mathrm{H})$. Supported by two steps Bremer and $77 \%$ Bootstrap.

6. Slender-skulled trematopids (Tambachia, Anconastes, Phonerpeton, and Acheloma). Based on two unambiguous synapomorphies $(41,42)$ and one homoplasy (44H). Supported by only one step Bremer and $<50 \%$ Bootstrap.

7. Advanced trematopids (Phonerpeton + Acheloma). Based on one unambiguous synapomorphy (27) and one homoplasy $(40 \mathrm{H})$. Supported by only three steps Bremer and $80 \%$ Bootstrap.

8. Dissorophidae (Platyhystrix, Aspidosaurus, Dissorophinae, and greater cacopine clade). Based on two unambiguous synapomorphies $(26,54)$ and one homoplasy $(4 \mathrm{H})$. Supported by three steps Bremer and $93 \%$ Bootstrap.

9. Armoured Dissorophidae (Aspidosaurus, Dissorophinae, and greater cacopine clade). Based on two unambiguous synapomorphies $(57,58-2)$. Supported by only one step Bremer and $60 \%$ Bootstrap.

10. Dissorophinae + Conjunctio multidens + greater cacopine clade (unresolved trichotomy). Based on two unambiguous synapomorphies $(10,59)$. Supported by only one step Bremer and $<50 \%$ Bootstrap.

11. Dissorophinae (Dissorophus, Broiliellus). Based on only one homoplasy $(66 \mathrm{H})$. Supported by one step Bremer and $76 \%$ Bootstrap. 


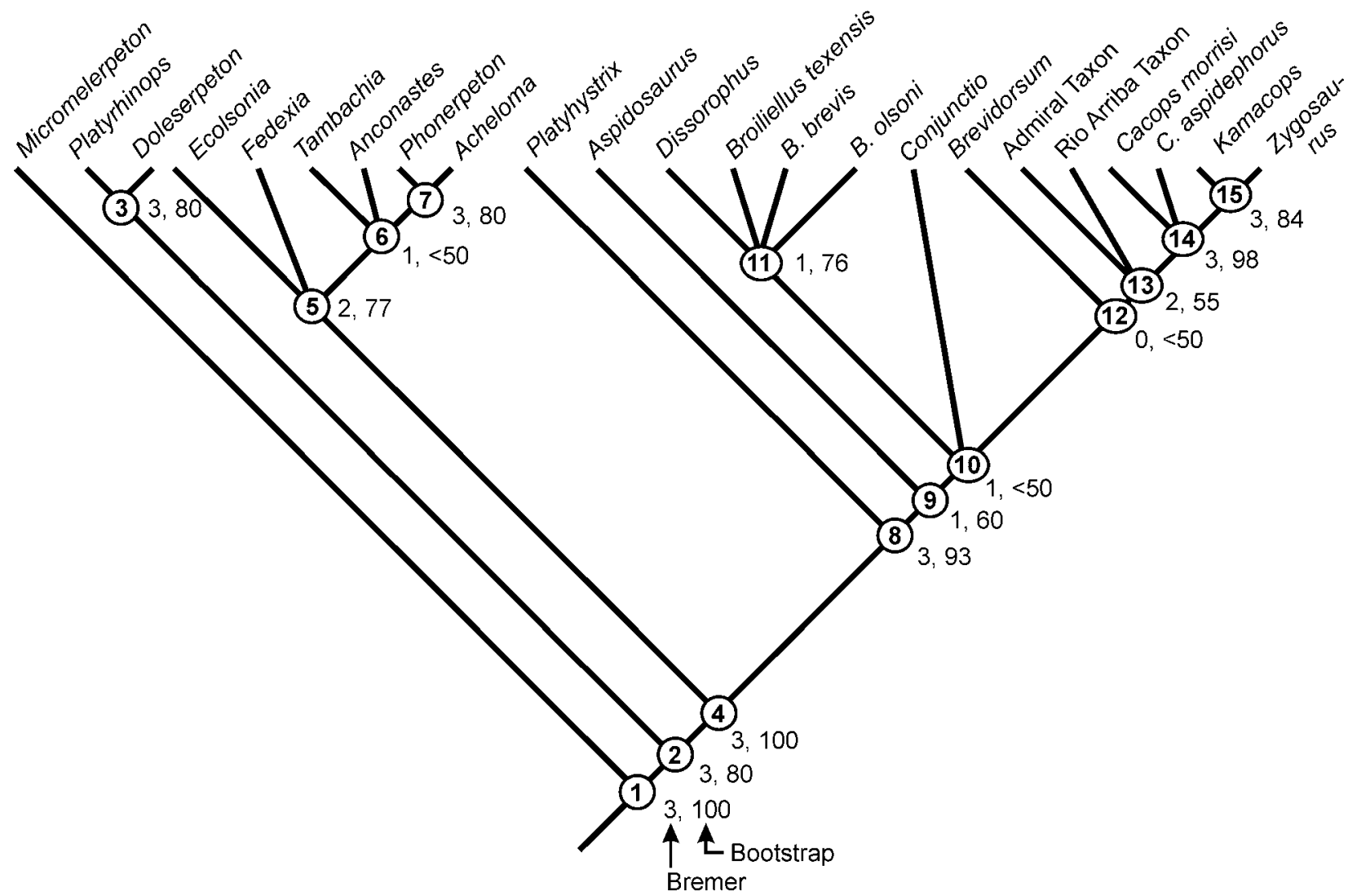

Figure 5. Phylogeny of dissorophoids based on the present PAUP analysis. Outgroup: Sclerocephalus. Numbers in circles refer to nodes discussed in the text. Robustness of each node measured by Bremer and Bootstrap.

12. Greater cacopine clade (Brevidorsum, Admiral Taxon, Rio Arriba Taxon, and Cacopinae). This clade is based on two homoplasies $(17 \mathrm{H}, 49 \mathrm{H})$ and has only very poor support data, no Bremer decay value, $<50 \%$ Bootstrap.

13. Admiral Taxon, Rio Arriba Taxon, and Cacopinae (unresolved trichotomy). This node is very poorly supported, with one step Bremer and $<50 \%$ Bootstrap (PAUP). A subset of this taxon sample, without the Admiral Taxon, is supported as a clade by two homoplasies $(50 \mathrm{H}, 55 \mathrm{H})$ and $55 \%$ Bootstrap.

14. Cacopinae (Cacops morrisi, C. aspidephorus, Kamacops, and Zygosaurus). Based on three unambiguous synapomorphies $(37,47,62)$ and one homoplasy $(45 \mathrm{H})$. Supported by three steps Bremer and $98 \%$ Bootstrap.

15. Kamacops + Zygosaurus. This final node does not share synapomorphies, but is supported by three steps Bremer and $84 \%$ Bootstrap.

\section{Variant analyses and robustness of nodes}

The robustness of the resulting topology was further tested by biased analyses in MacClade 3.0, addressing formerly open questions with respect to the position of certain taxa.

(1) Ecolsonia has been variously found to nest with trematopids or dissorophids (Schoch \& Rubidge
2005; Anderson et al. 2008; Berman et al. 2010). In the present analysis, it always nests with trematopids, in various permutations with Fedexia and the other trematopids. In the present data set, Ecolsonia requires six extra steps to nest with the dissorophids.

(2) The Admiral Taxon (Conjunctio sp. of Carroll 1964) shares some cranial features with amphibamids, especially the proportions of the posterior skull table and otic notch. However, it requires 9 extra steps to nest with amphibamids rather than cacopine dissorophids.

(3) The Rio Arriba Taxon (UCMP 40103) was catalogued as "Broiliellus" novomexicanus in the UCMP collection. Nesting with Broiliellus rather than cacopines requires four extra steps.

(4) Amphibamids and dissorophids share a range of derived features not found in trematopids. This includes the wide interorbital region (only present in some amphibamids), the reduction of the pterygoid, the lateral expansion of the interpterygoid vacuities, and proportions of the posterior skull table (only shared by some cacopines). An amphibamid-dissorophid clade requires eight extra steps, and a nesting of Amphibamidae only with the Dissorophinae (Dissorophus and Broiliellus, sharing the largest number of characters with amphibamids) also requires eight additional steps. This adds to the picture that Olsoniformes, Amphibamidae, and Dissorophidae are relatively robust monophyla. 
(5) Micromelerpeton and the Amphibamidae have been found to nest together by some previous authors (Anderson et al. 2008). This group requires two extra steps in the present analysis.

\section{Character evolution}

The monophyletic status of the Dissorophoidea has not been questioned since Bolt (1969), and there is a broad consensus in the recent literature (Boy 1972; Daly 1994; Schoch \& Rubidge 2005; Ruta \& Bolt 2006; Fröbisch \& Reisz 2008; Anderson et al. 2008; Fröbisch \& Schoch 2009; Polley \& Reisz 2011). In turn, the relationships of dissorophoids to other temnospondyls are still very inadequately understood (Schoch in press). Three often emerging, alternative hypotheses are a dissorophoid-dvinosaur clade (Ruta \& Bolt 2006), a dissorophoid-eryopid clade (Milner 1990; Yates \& Warren 2000), and dissorophoids nesting with eryopids and stereospondylomorphs (Holmes et al. 1998). Identification of the dissorophoid sister group within temnospondyls has a profound impact on character polarity (Schoch in press). As long as this remains an open question, there will be major problems for the interpretation of character evolution within the Dissorophoidea.

Within dissorophoids, I lean towards Milner's (1990) hypothesis that Micromelerpetontidae forms the basalmost group. The short and stout humerus, elongate trunk with 27-29 presacral vertebrae, and the long postorbital skull table are consistent with the condition in various other temnospondyl groups (Schoch in press). The present analysis confirms this view, but Anderson et al. (2008) have favoured an alternative hypothesis in which Micromelerpeton nests with the Amphibamidae. The shared presence of palpebral ossifications added to this pattern, but this is invalidated by the occurrence of such ossicles in Broiliellus texensis, Brevidorsum, and Cacops morrisi.

The post-micromelerpetontid dissorophoids include the Amphibamidae and Olsoniformes; the Branchiosauridae have not been considered here, but were recently found to nest within amphibamids (Schoch \& Milner 2008; Fröbisch \& Schoch 2009). The abbreviated interclavicle - much wider than long and usually pentagonal - is shared by all amphibamids, trematopids, and dissorophids with the exception of Cacops aspidephorus, where is bears a posterior stylus (Williston 1910a) that is probably derived. However, there is a range of additional characters supporting a clade of amphibamids and olsoniforms: the narial flange (13), the foreshortened supratemporal-squamosal suture (18), the greater parietal width (29), and the absence of a vomerine tooth arcade (33). In contrast to these features, the enlarged interpterygoid vacuities and the reduction of lateral palate elements appear to have evolved in parallel in amphibamids and dissorophoids: this is not only indicated by the possession of the plesiomorphic state in trematopids (which retain the pterygoid-vomer contact for instance), but more importantly by the slightly different architecture of amphibamid and dissorophid palates. Whereas amphibamids reduced the width of the posterior palatine and ectopterygoid (reaching a minimum in Doleserpeton, which might even have lost the ecotpterygoid - see Sigurdsen \& Bolt 2010), dissorophids retained relatively broad palatine and ectopterygoid bones accommodating a foreshortened pterygoid. In adult Cacops morrisi and Kamacops, the palatine encloses the tip of the pterygoid medially, a condition that differs remarkably from all other temnospondyls. However, this character has not been coded here because its occurrence in dissorophids is currently unknown. In cacopines, this region is also further obscured by firmly attached palatal ossicles, which are sometimes fused to underlying elements (Schoch 1999). These ossicles are known from a wide range of temnospondyls and are especially common in dissorophoids (Carroll 1964; Fröbisch \& Reisz 2008). The enlargement of the interpterygoid vacuities might have been triggered by an increasing importance of the retractor bulbi (Schoch \& Rubidge 2005), but could also reflect increased area for buccal pumping, both of which might well have evolved in parallel in the terrestrial amphibamids and dissoropids.

The monophyly of the Amphibamidae was not a focus here, and has been analyzed elsewhere with various permutations of taxa and characters (Schoch \& Rubidge 2005; Huttenlocker et al. 2007; Anderson et al. 2008; Fröbisch \& Reisz 2008; Schoch \& Milner 2008; Bourget \& Anderson 2011). As these studies all agreed that Platyrhinops and Doleserpeton fall within a monophyletic Amphibamidae, they have been chosen as representative taxa here. Still, the miniature nature of most amphibamids lends support to the suspicion that the absence of osteoderms in these taxa may be caused by their small size or juvenility of the preserved samples. However, this view is not supported by the absence of osteoderms even in relatively large amphibamids and their presence in small adult or immature dissorophids (e.g., Broiliellus brevis, Admiral Taxon). Still, amphibamids may be viewed as an assemblage of immature and small-scale dissorophids, and indeed some features are shared between the two groups $(12,23,68)$. However, there are clear-cut amphibamid characters that do not occur in any dissorophid: (1) the extremely reduced palatine and ectopterygoid, (2) the delicate rod-like humerus lacking any processes, (3) the enlarged and ventrally expanded pleurocentra that formed closed cylinders in the most derived taxa (Daly 1994), (4) the undifferentiated, abbreviated ribs which are not enlarged in the anterior trunk, and (5) the minute cleithrum. Especially the humerus, ribs, and cleithrum may be suggested to result from scaling or immaturity, but outgroups reveal that larvae of other temnospondyls (Sclerocephalus, Onchiodon, Acanthostomatops) do not look like amphibamids (Boy 1988, 1990; Schoch 2003; Witzmann 2005; Witzmann \& Schoch 2006). 
The Olsoniformes (Trematopidae + Dissorophidae) are well-supported in all variants of the present analysis. They share the stout and low ilium, the expanded distal end of the humerus with its large condyles, the very thin cultriform process, and the naris with septomaxilla in mid-level position. The latter feature formed a condition that paved the way for the further modification of the trematopid naris. In contrast to dissorophids, trematopids greatly expanded the narial region posterior to the septomaxilla at the expense of the lacrimal. Instead, the lacrimal is never reduced in dissorophids.

The monophyly of the Trematopidae and their distinctness from all dissorophids are not only revealed by their apomorphic narial region. Plesiomorphic characters not found in any dissorophid are the denticle field on the parasphenoid and especially the sutural contact between the pterygoid and vomer, sealing off the palatine and ectopterygoid from the interpterygoid vacuity. In basal taxa (Tambachia, Ecolsonia) the palatine ramus of the pterygoid is particularly robust, recalling the situation in Sclerocephalus. Altogether, the monophyly of trematopids is well-established, including even the formerly controversial Ecolsonia (Berman et al. 1985). Contrasting Polley \& Reisz (2011), the current findings revert their phylogenetic sequence into Ecolsonia (basalmost) - Tambachia/Anconastes - Phonerpeton + Acheloma (most derived). This is partly based on the inclusion of many additional dissorophids not considered by Polley \& Reisz (2011), notably dissorophines, which all lack the internarial fenestra. Rather than having evolved just once, retained in Phonerpeton and Acheloma, and lost in other trematopids, it probably evolved convergently in cacopines and Acheloma + Phonerpeton. This is not surprising, as the internarial fenestra also occurs in some amphibamids, branchiosaurids, and a few micromelerpetontids (Carroll 1964; Boy 1987, 1995).

Most interestingly in the present context, the monophyly of the Dissorophidae is well-supported and does not hinge at the presence and composition of their osteoderms (Fig. 7). Instead, it is largely based on cranial characters. These are not restricted to a single region or otherwise correlated, but found in different anatomical areas: the completely sutured basipterygoid region, loss of denticles on the parasphenoid, loss of contact between pterygoid and vomer, and a foreshortened postorbital. A derived postcranial feature is the absence of the supinator on the humerus, which is probably convergent in amphibamids and dissorophids, because trematopids retain a supinator.

When the two osteoderm characters $(57,58)$ are omitted, the dissorophids are still found as a monophylum. Apart from the increased number of MPTs (809 trees, 137 steps), the only significant topological change imposed by this omission is the decomposition of the Dissorophinae as a clade. There, Dissorophus and Broiliellus fall on a grade between Platyhystrix/Aspidosaurus and the Cacopinae.
The best-supported nodes within the Dissorophidae are the dichotomy between dissorophines and cacopines and the monophyly of Cacops, Kamacops, and Zygosaurus (Fig. 6). Dissorophines and cacopines share the pattern of pronounced and continuous ridges on the skull roof (59), which is only rudimentarily present in outgroups. This unnamed group shares with Aspidosaurus the presence of internal osteoderms (57), which is somewhat controversial because of the different relation of these plates with the neural arch. However, contrasting DeMar's (1966) claim, there is no reason why the two different types of internal osteoderm could not have been derived from a more simple plate in the last common ancestor of Aspidosaurus, Dissorophinae, and Cacopinae: the modes of attachment (fusion with dorsal spine or wedged between successive neural arches) might well have evolved thereafter. This said, the similarity between Aspidosaurus and Cacops osteoderms provides conflicting evidence, provided that Aspidosaurus really nested below the dissorophine-cacopine split as found here. At any rate, Platyhystrix nests at a more basal node, prior to the evolution of the dissorophid osteoderms, which is in agreement with stratigraphy and makes the numerous small ossicles in the dorsum of Ecolsonia a convergence.

The Dissorophinae are defined by a range of characters located in different body regions. In the palate, the interpterygoid vacuities are extremely wide, resembling the condition in some derived amphibamids; this differs from amphibamids in the retention of relatively wide and flat palatine and ectopterygoid bones bearing a shagreen of teeth and retaining tusks. The parasphenoid bears posterolateral wings, which are most pronounced in dissorophines. The dissorophine skull bears remarkable eminences (bosses, ridges, or larger areas) on the medial skull bones and the jugal. Although most eminences are confined to a smaller set of taxa each, it is likely that they were subject to variation, ontogeny, or scaling - thus, they may well have been inherited from a common dissorophine ancestor. Future work on dissorophines requires closer examination of the different Broiliellus species and their relationship to Dissorophus multicinctus, all of which remainig neglected taxa.

The Cacopinae are defined by a gap between the exoccipital and postparietal (37), the closed otic notch and its peculiar posteroventrally indented margin $(45 \mathrm{H})$, the knobby exostoses on the skull roof and mandible which in adults of all three genera have resulted in a large-scale fusion of dermal bones (47), and the unique configuration of the carotid artery channel on the parasphenoid: rather than the basal plate, the openings for the carotid are located on the cultriform process (62). Zygosaurus, although based on a single now-lost specimen, is definitely different from Cacops and Kamacops by its larger orbits and the abbreviated otic notches. Future studies on cacopines should focus on the braincase and ontogenetic data of Cacops morrisi yet to be analyzed. 


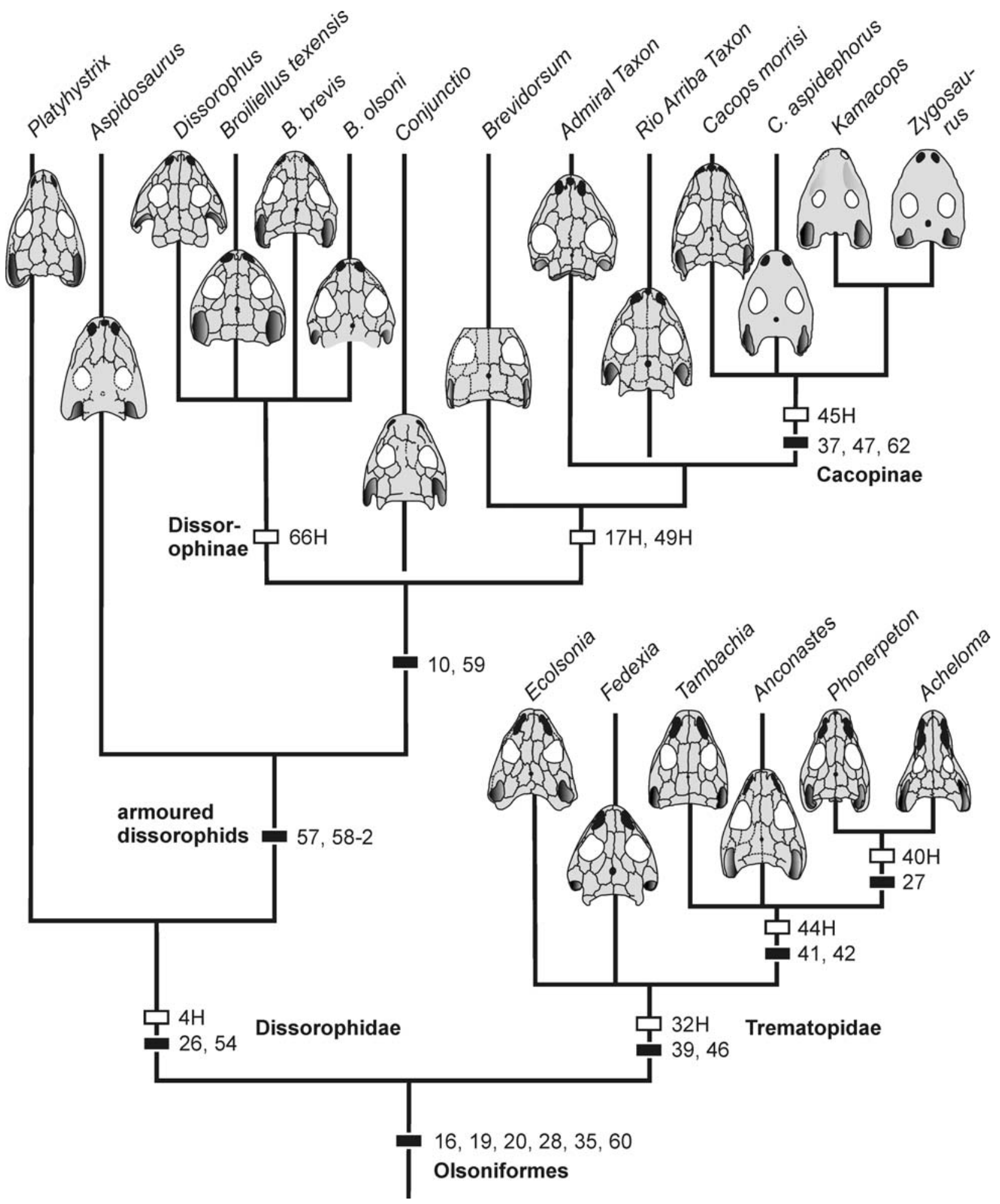

Figure 6. Phylogeny of dissorophids and trematopids as found in the present analysis. Support by unambiguous synapomorphies (black rectangles) and homoplasies (white rectangles) mapped on nodes.

\section{Conclusions}

(1) The Dissorophidae and Trematopidae each form monophyletic groups that are more closely related to one another than either of them is to amphibamids. The present analysis thus confirms the concept of a monophyletic Olsoniformes (Anderson et al.
2008). Olsoniformes and Amphibamidae are each defined by clear-cut autapomorphies, making it unlikely that amphibamids are dwarfed dissorophids or olsoniforms.

(2) Ecolsonia nests always with Fedexia at the base of the Trematopidae, rather than falling with the dissorophids as suggested by previous authors. 


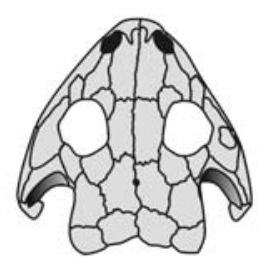

Dissorophus

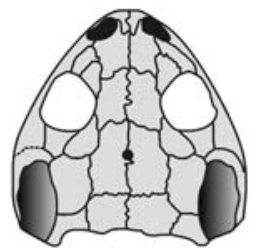

Broiliellus

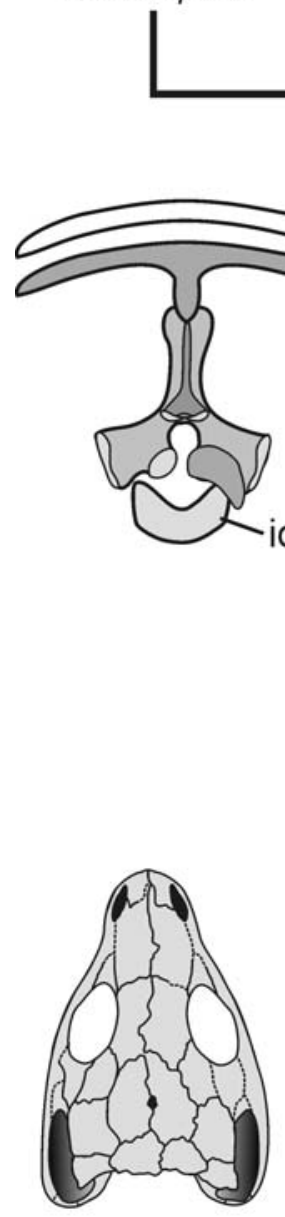

Platyhystrix

ic

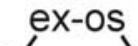

.

Dissorophinae

no osteoderms

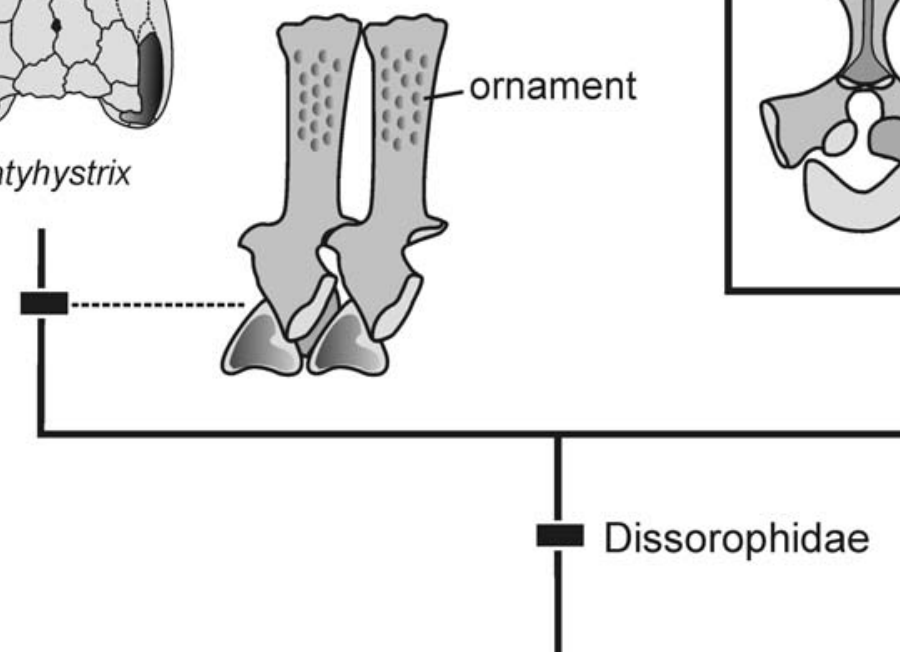

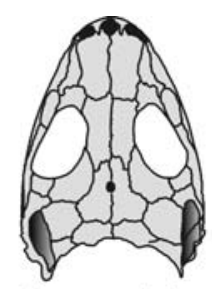

C. morrisi

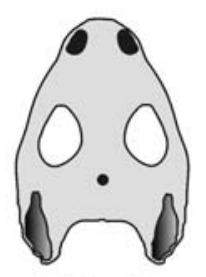

C. aspidephorus
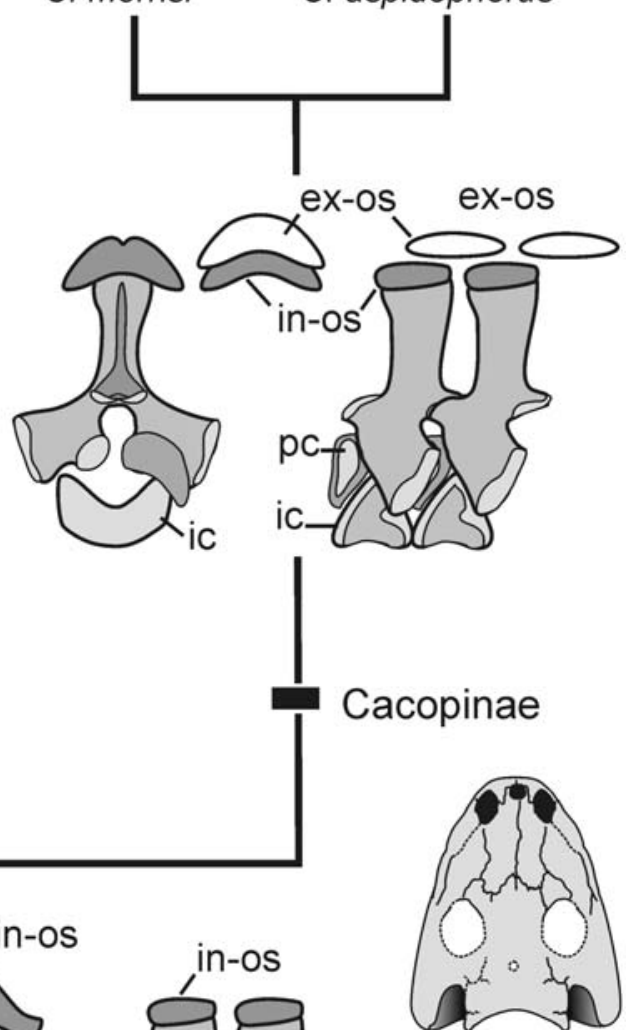

Aspidosaurus

Figure 7. Distribution of osteoderm and vertebral characters in the Dissorophidae. Only some derived dissorophid taxa share two series of osteoderms, and the structural differences of the internal osteoderms are considerable: alternating with neural arches in dissorophines and fused to dorsal spines in cacopines. These characters are still poorly known or unknown in many taxa.

(3) The Dissorophidae falls into two major clades, the Dissorophinae (Dissorophus, Broiliellus) and the Cacopinae (Cacops, Kamacops, Zygosaurus). Among these, the Cacopinae forms much more robust a node than the Dissorophinae.
(4) Platyhystrix and Aspidosaurus form successive sister taxa of all other dissorophids.

(5) Incompletely known taxa were found to nest as follows: (a) Brevidorsum, the Admiral Taxon and Rio Arriba Taxon at the base of the Cacopinae and (b) 
Conjunctio multidens (only the type specimen) forming an unresolved trichotomy with dissorophines and cacopines.

\section{Acknowledgements}

I thank Jessica Cundiff, Eugene Gaffney, Yurij Gubin, Pat Holroyd, Farish Jenkins, Robert Reisz, and Hans-Dieter Sues for granting access to material under their care. Ralf Werneburg and Olivier Rieppel were most helpful by providing additional photos of material at FMNH and CM, and Florian Witzmann from Kamacops and Zygosaurus. Preparation was carried out by Norbert Adorf (Cacops morrisi) and Achim Lehmkuhl ("Broiliellus" novomexicanus) who did their usual marvellous job. I am grateful to Nadia Fröbisch and Jean-Sébastien Steyer for their constructive reviews, and the editor for helpful suggestions.

\section{References}

Anderson, J. S., Henrici, A., Sumida, S. S., Martens, T. \& Berman, D. S 2008. Georgenthalia clavinasica, a new genus and species of dissorophoid temnospondyl from the early Permian of Germany, and the relationships of the family Amphibamidae. - Journal of Vertebrate Paleontology 28: 61-75.

Berman, D. S. \& Lucas, S. G. 2003. Aspidosaurus binasser (Amphibia, Temnospondyli), a new species of Dissorophidae from the Lower Permian of Texas. - Annals of Carnegie Museum 72: 241-262.

Berman, D. S., Reisz, R. R. \& Fracasso, M. A. 1981. Skull of the Lower Permian dissorophid amphibian Platyhystrix rugosus. Annals of the Carnegie Museum 50: 391-416.

Berman, D. S., Reisz, R. R. \& Eberth, D. A. 1985. Ecolsonia cutlerensis, an Early Permian dissorophid amphibian from the Cutler Formation of north-central New Mexico. - New Mexico Bureau of Mines and Mineral Resources Circular 191: 1-31.

Berman, D. S., Reisz, R. R. \& Eberth, D. A. 1987. A new genus and species of trematopid amphibian from the Late Pennsylvanian of north-central New Mexico. - Journal of Vertebrate Paleontology 7: $252-269$

Berman, D. S., Henrici, A. C., Brezinski, D. K. \& Kollar, A. D. 2010. A new trematopid amphibian (Temnospondyli: Dissorophoidea) from the Upper Pennsylvanian of western Pennsylvania: earliest record of terrestrial vertebrates responding to a warmer, drier climate. - Annals of the Carnegie Museum 78: 289-318.

Bolt, J. R. 1969. Lissamphibian origins: possible protolissamphibian from the Lower Permian of Oklahoma. - Science 166: 888-891.

Bolt, J. R. 1974a. Armor of dissorophids (Amphibia: Labyrinthodontia): an examination of its taxonomic use and report of a new occurrence. - Journal of Paleontology 48: 135-142.

Bolt, J. R. 1974b. A trematopsid skull from the Lower Permian, and analysis of some characters of the dissorophid otic notch. Fieldiana: Geology 30: 67-79.

Bourget, H. \& Anderson, J. S. 2011. A new amphibamid (Temnospondyli: Dissorophoidea) from the Early Permian of Texas. - Journal of Vertebrate Paleontology 31: 32-49.

Boy J. A. 1972. Die Branchiosaurier (Amphibia) des saarpfälzischen Rotliegenden (Perm, SW-Deutschland). - Abhandlungen des hessischen Landesamts Bodenforschung 65: 6-137.

Boy, J. A. 1981. Zur Anwendung der Hennigschen Methode in der Wirbeltierpaläontologie. - Paläontologische Zeitschrift 55: 87-107.

Boy J. A. 1987. Studien über die Branchiosauridae (Amphibia: Temnospondyli; Ober-Karbon - Unter-Perm. Systematische Übersicht. - Neues Jahrbuch für Geologie und Paläontologie Abhandlungen 174: $75-104$.
Boy, J. A. 1988. Über einige Vertreter der Eryopoidea (Amphibia: Temnospondyli) aus dem europäischen Rotliegend (? höchstes Karbon - Perm). 1. Sclerocephalus. - Paläontologische Zeitschrift 62: $107-132$.

Boy, J. A. 1990. Über einige Vertreter der Eryopoidea (Amphibia: Temnospondyli) aus dem europäischen Rotliegend (? höchstes Karbon - Perm). 3. Onchiodon. - Paläontologische Zeitschrift 64: $287-312$.

Boy, J. A. 1995. Über die Micromelerpetontidae (Amphibia: Temnospondyli). 1. Morphologie und Paläoökologie des Micromelerpeton credneri (Unter-Perm; SW-Deutschland). - Paläontologische Zeitschrift 69: 429-457.

Carroll, R. L. 1964. The early evolution of the dissorophid amhibians. Bulletin of the Museum of Comparative Zoology 131: 161-250.

Clack, J. A. \& Milner, A. R. 2010. Morphology and systematics of the Pennsylvanian amphibian Platyrhinops lyelli (Amphibia: Temnospondyli). - Transactions of the Royal Society of Edinburgh, Earth Sciences 100: 275-295.

Case, E. C. \& Williston, S. W. 1913. A description of Aspidosaurus novomexicanus. - Carnegie Institute Washington 181: 7-9.

Daly, E. 1994. The Amphibamidae (Amphibia: Temnospondyli) with a description of a new genus from the Upper Pennsylvanian of Kansas. - Miscellaneous Publications of the University of Kansas Museum of Natural History 85: 1-59.

DeMar, R. E. 1966a. Longiscitula houghae, a new genus of dissorophid amphibian from the Permian of Texas. - Fieldiana: Geology 16: $45-53$.

DeMar, R. E. 1966b. The functional and phylogenetic significance of the armor of dissorophid amphibians. - Fieldiana: Geology 16: $55-88$.

DeMar, R. E. 1967. Two new species of Broiliellus (Amphibians) from the Permian of Texas. - Fieldiana: Geology 16: 117-129.

DeMar, R. E. 1968. The Permian labyrinthodont Dissorophus multicinctus, and adaptations of the family Dissorophidae. - Journal of Paleontology 42: 1210-1242.

Dilkes, D. 1990. A new trematopsid amphibian (Temnospondyli: Dissorophoidea) from the Lower Permian of Texas. - Journal of Vertebrate Paleontology 10: 222-243.

Dilkes, D. 1993. Biology and evolution of the nasal region in trematopid amphibians. - Palaeontology 36: 839-853.

Dilkes, D. 2009. Comparison and biomechanical interpretation of the vertebrae and osteoderms of Cacops aspidephorus and Dissorophus multicinctus (Temnospondyli, Dissorophidae). - Journal of Vertebrate Paleontology 29: 1013-1021.

Dilkes, D. \& Brown, L. E. 2007. Biomechanics of the vertebrae and associated osteoderms of the Early Permian amphibian Cacops aspidephorus. - Journal of Zoology 271: 396-407.

Dilkes, D. \& Reisz, R. R. 1987. Trematops milleri Williston, 1909 identified as a junior synonym of Acheloma cumminsi Cope 1882, with a revision of the genus. - American Museum Novitates 2902: $1-12$.

Eaton, T. H. 1973. A Pennsylvanian dissorophid amphibian from Kansas. - Occasional Papers of the Museum of Natural History University of Kansas 14: 1-8.

Eichwald, E. 1848. Über die Saurier des kupferführenden Zechsteins Russlands. - Bulletin de la Société National Moscou 21: 136-204.

Fröbisch, N. B. \& Reisz, R. R. 2008. A new Lower Permian amphibamid (Dissorophoidea: Temnospondyli) from the fissure fill deposits near Richards Spur, Oklahoma. - Journal of Vertebrate Paleontology 28: 1015-1030.

Fröbisch, N. B. \& Reisz, R. R. 2012. A New Species of Dissorophid (Cacops woehri) from the Lower Permian Dolese Quarry, Near Richards Spur, Oklahoma. - Journal of Vertebrate Paleontology 32: 35-44.

Fröbisch, N. B. \& Schoch, R. R. 2009. Testing the impact of miniaturization on phylogeny: Paleozoic dissorophoid amphibians. Systematic Biology 58: 312-327. 
Gubin, Y. M. 1980. New Permian dissorophids of the Ural forelands. - Paleontologiceskij Zhurnal 1980 (3): 82-90.

Holmes, R. B., Carroll, R. L. \& Reisz, R. R. 1998. The first articulated skeleton of Dendrerpeton acadianum (Temnospondyli, Dendrerpetontidae) from the Lower Pennsylvanian locality of Joggins, Nova Scotia, and a review of its relationships. - Journal of Vertebrate Paleontology 18: 64-79.

Huttenlocker, A. K., Pardo, J. D. \& Small, B. K. 2007. Plemmyradytes shintoni, gen. et sp. nov., an Early Permian amphibamid (Temnospondyli: Dissorophoidea) from the Eskridge Formation, Nebraska. - Journal of Vertebrate Paleontology 27: 316-328.

Jarvik, E. 1996. The Devonian tetrapod Ichthyostega. - Fossils and Strata 40: 1-213.

Li, J-L. \& Cheng, Z-W. 1999. New anthracosaur and temnospondyl amphibians from Gansu, China - the fifth report on late Permian Dashankou lower tetrapod fauna. - Vertebrata Palasiatica 37: 242-247.

Maddison, W. P. \& Maddison, D. R. 1992. MacClade: Analysis of phylogeny and character evolution. Sunderland/Mass (Sinauer).

Milner, A.R. 1988. The relationships and origin of living amphibians. In Benton, M. J. (ed.). The Phylogeny and Classification of the Tetrapods. Volume 1. Clarendon Press, Oxford: pp. 59-102.

Milner, A. R. 1990. The radiations of temnospondyl amphibians. In Taylor, P. D. \& Larwood, G. P. (eds). Major evolutionary radiations. Clarendon Press, Oxford: pp. 321-349.

Milner, A. R. 1993. The Paleozoic relatives of lissamphibians. - Herpetological Monograph 7: 8-27.

Milner, A. R. 2003. Longiscitula houghae DeMar, 1966 (Amphibia: Temnospondyli), a junior synonym of Dissorophus multicinctus Cope, 1895. - Journal of Vertebrate Paleontology 23: 941-944.

Polley, B. \& Reisz, R. R. 2011. A new Lower Permian trematopid (Temnospondyli: Dissorophoidea) from Richards Spur, Oklahoma. - Zoological Journal of the Linnean Society 161: 789-815.

Reisz, R. R., Schoch, R. R. \& Anderson, J. S. 2009. The armoured dissorophid Cacops from the Early Permian of Oklahoma and the exploitation of the terrestrial realm by amphibians. - Naturwissenschaften 96: 789-796.

Ruta, M., Coates, M. I. \& Quicke, D. L. J. 2003. Early tetrapod relationships revisited. - Biological Reviews 78: 251-345.

Ruta, M. \& Bolt, J. R. 2006. A reassessment of the temnospondyl amphibian Peryella olsoni from the Lower Permian of Oklahoma. - Transactions of the Royal Society of Edinburgh Earth Science 97: $113-165$.

Schoch, R. R. 1999. Studies on braincases of early tetrapods: structure, morphological diversity, and phylogeny. 2. Kamacops acervalis and other advanced dissorophoids. - Neues Jahrbuch für Geologie und Paläontologie Abhandlungen 213: 289-312.

Schoch, R. R. 2000. The origin and intrarelationships of capitosaurid amphibians. - Palaeontology 43: 705-727.

Schoch, R. R. 2003. The early larval ontogeny of the Permo-Carboniferous temnospondyl Sclerocephalus. - Palaeontology 46: 10551072 .

\section{Appendix}

\section{Character-taxon matrix}

Abbreviations: Den, Dendrerpeton; Scl, Sclerocephalus; Mic, Micropmelerpeton; Pla, Platyhystrix; Dol, Doleserpeton; Ach, Acheloma; Pho, Phonerpeton; Anc, Anconastes; Fed, Fedexia; Tam, Tambachia; Eco, Ecolsonia; Asp, Aspidosau-
Schoch, R. R. 2009. The evolution of life cycles in early amphibians. - Annual Review of Earth and Planetary Sciences 37: 135-162.

Schoch, R. R. in press. The major clades of temnospondyls: an inclusive phylogenetic analysis. - Journal of Systematic Palaeontology.

Schoch, R. R. \& Milner, A. R. 2008. The intrarelationships and evolutionary history of the temnospondyl family Branchiosauridae. Journal of Systematic Palaeontology 6: 409-431.

Schoch, R. R. \& Rubidge, B. S. 2005. The amphibamid Micropholis from the Lystrosaurus Assemblage Zone of South Africa. - Journal of Vertebrate Paleontology 25: 502-522.

Schoch, R. R. \& Witzmann, F. 2009. Osteology and relationships of the temnospondyl genus Sclerocephalus. - Zoological Journal of the Linnean Society London 157: 135-168.

Sigurdsen, T. \& Bolt, J. R. 2010. The Lower Permian amphibamid Doleserpeton (Temnospondyli: Dissorophoidea), the intrarelationships of amphibamids, and the origin of modern amphibians. Journal of Vertebrate Paleontology 30: 1360-1377.

Sumida, S. S., Berman, D. S. \& Martens, T. 1998. A new trematopid amphibian from the Lower Permian of central Germany. - Palaeontology 41: 605-629.

Swofford, D. 1991. PAUP: phylogenetic analysis using parsimony. Version 3.1. Illinois. Natural History Survey, Champaign.

Watson, D. M. S. 1962. The evolution of the labyrinthodonts. - Philosophical Transactions of the Royal Society London B 245: 219265 .

Williston, S. W. 1909. New or little known Permian vertebrates: Trematops. - Journal of Geology 21: 636-658

Williston, S. W. 1910a. Cacops, Desmospondylus: new genera of Permian vertebrates. - Bulletin of the Geological Society of America 21: $249-284$.

Williston, S. W. 1910b. Dissorophus Cope. - Journal of Geology 18: 526-536.

Williston, S. W. 1914. Broiliellus, a new genus of amphibians from the Permian of Texas. - Journal of Geology 22: 49-56.

Witzmann, F. 2005. Hyobranchial and postcranial ontogeny of the temnospondyl Onchiodon labyrinthicus (Geinitz, 1861) from Niederhäslich (Döhlen Basin, Autunian, Saxony). - Paläontologische Zeitschrift 79: 479-492.

Witzmann, F. \& Pfretzschner, H.-U. 2003. Larval ontogeny of Micromelerpeton credneri (Temnospondyli, Dissorophoidea). - Journal of Vertebrate Paleontology 23: 750-768.

Witzmann, F. \& Schoch, R. R. 2006. Skeletal development of Acanthostomatops vorax from the Döhlen Basin of Saxony. - Transactions of the Royal Society of Edinburgh Earth Sciences 96: 365385

Yates, A. M. \& Warren, A. A. 2000. The phylogeny of the 'higher' temnospondyls (Vertebrata: Choanata) and its implications for the monophyly and origins of the Stereospondyli. - Zoological Journal of the Linnean Society London 128: 77-121.

rus; Phy, Platyhystrix; Dis, Dissorophus; Btx, Broiliellus texensis; Bbr, Broiliellus brevis; Bol, Broiliellus olsoni; Bre, Brevidorsum; Con, Conjunctio; AdT, Admiral Taxon; RAT, Rio Arriba Taxon; Cmo, Cacops morrisi; Cas, Cacops aspidephorus; Kam, Kamacops; Zyg, Zygosaurus. 


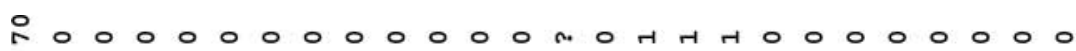

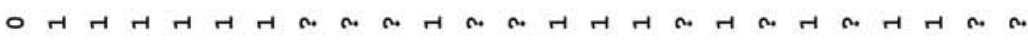

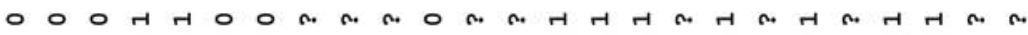

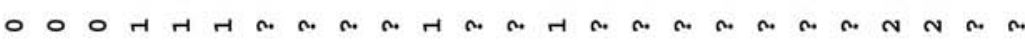

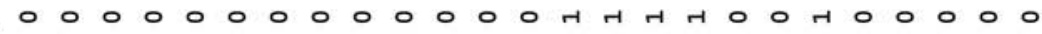

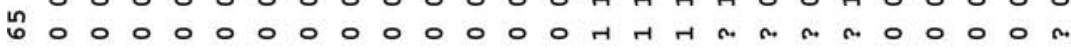

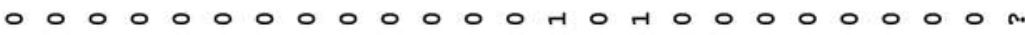

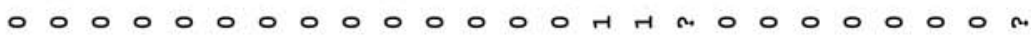

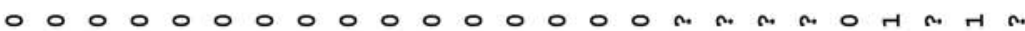

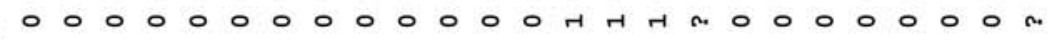

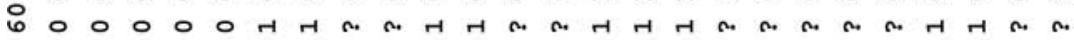

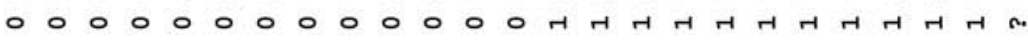

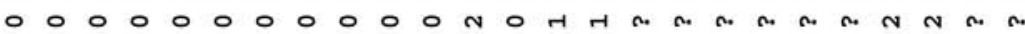

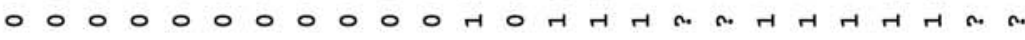

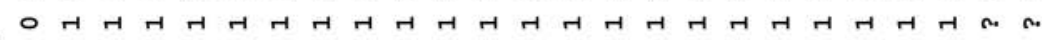

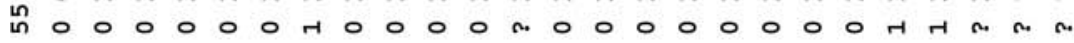

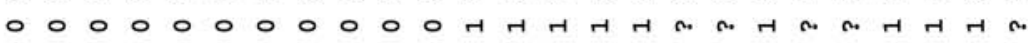

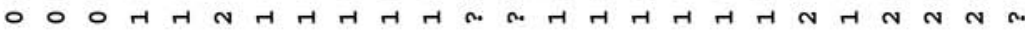

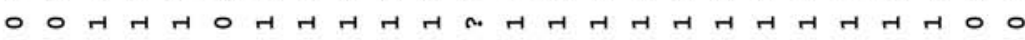

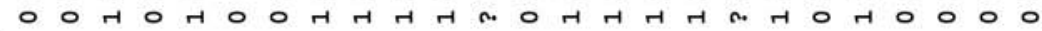

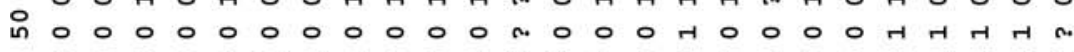

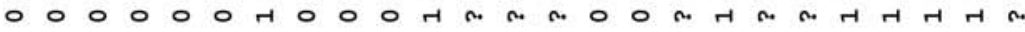

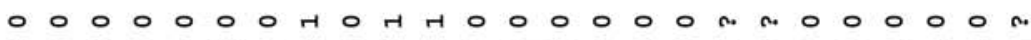

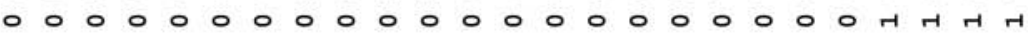

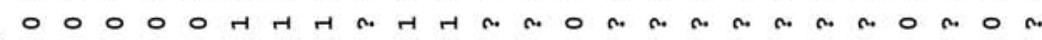

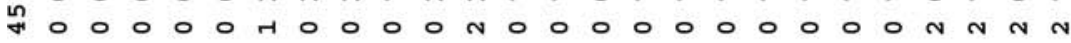

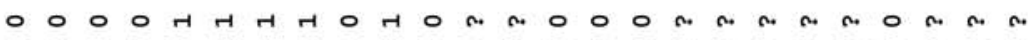

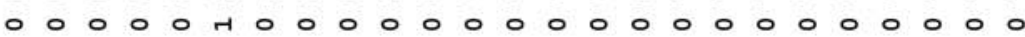

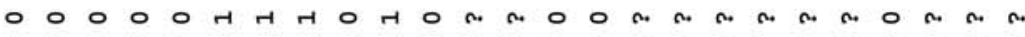

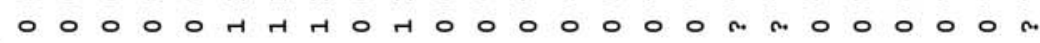

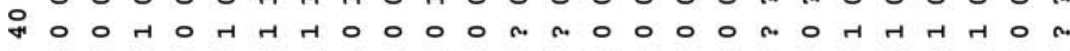

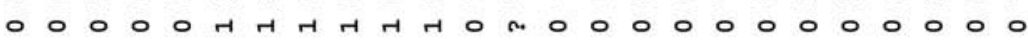

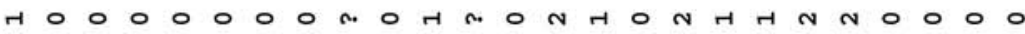

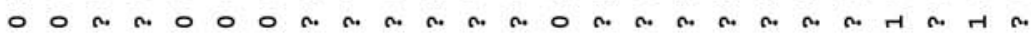

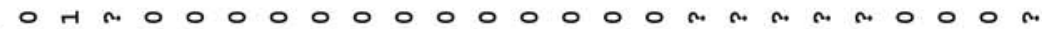

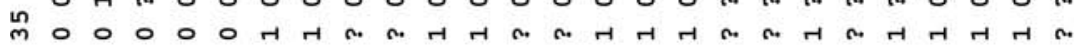

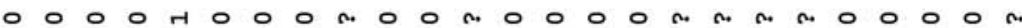

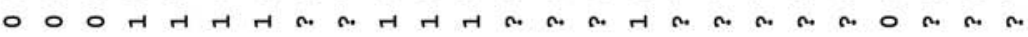
$0000004 H^{0}$

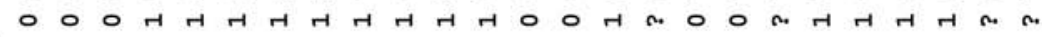

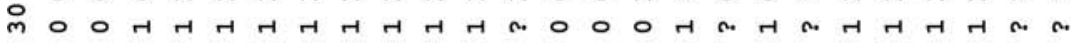

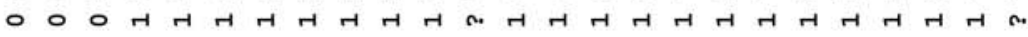

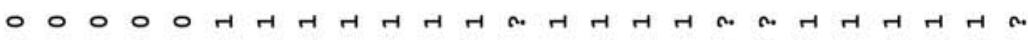

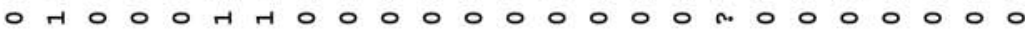

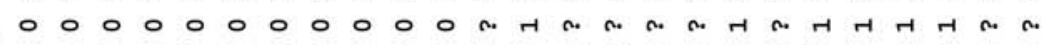

$\stackrel{n}{n} 0$

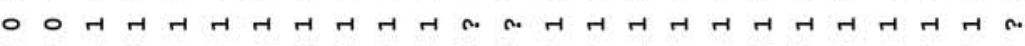
0 O 0 H

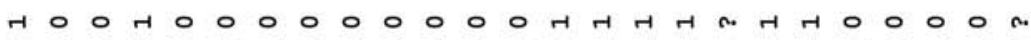

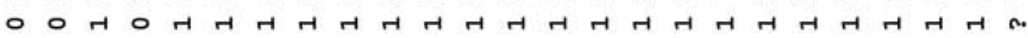

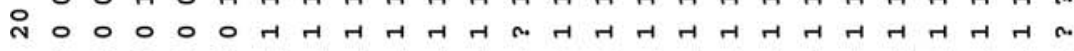

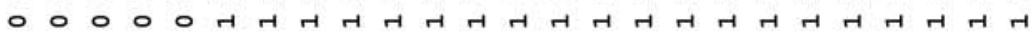

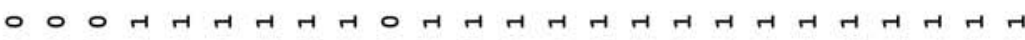

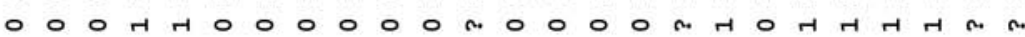

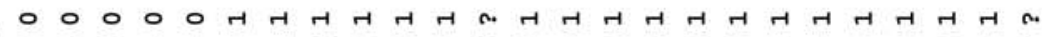

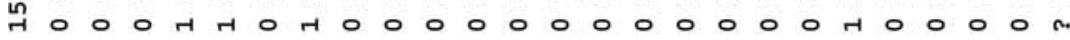

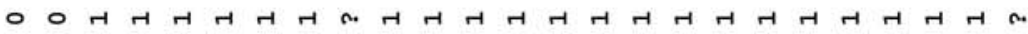

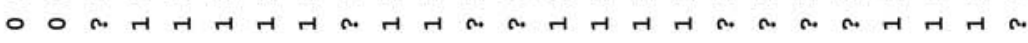

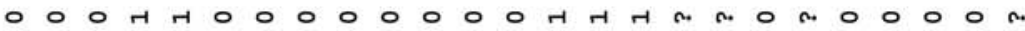

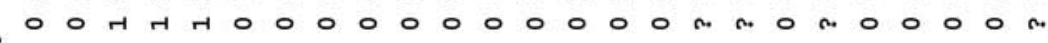

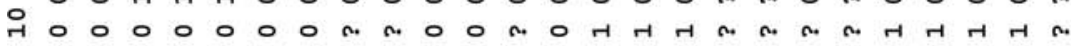

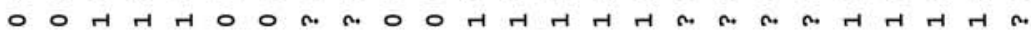

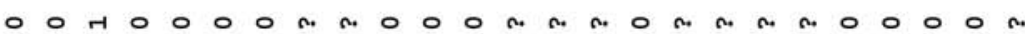

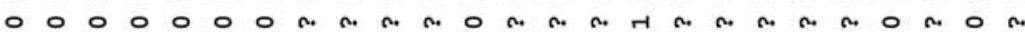

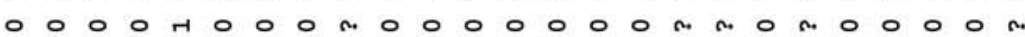
n 0 ○ 0 ○

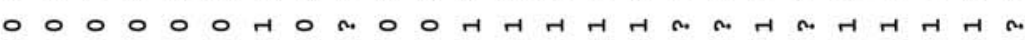

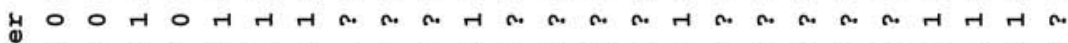

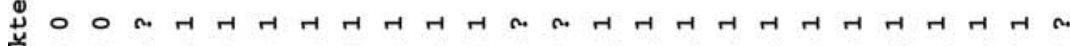

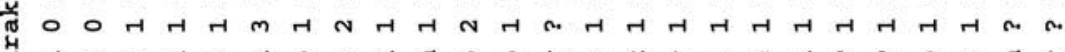

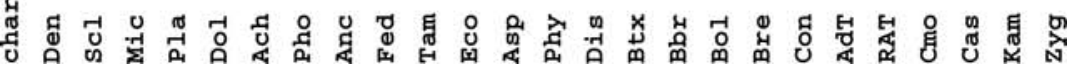

